\title{
6200 years of human activities and environmental change in the northern central Alps
}

\author{
Clemens von Scheffer ${ }^{1,2}$, Annika Lange ${ }^{1}$, François De Vleeschouwer ${ }^{2,3}$, Joachim Schrautzer ${ }^{1}$, and Ingmar Unkel ${ }^{1}$ \\ ${ }^{1}$ Institute for Ecosystem Research, Christian-Albrechts University, Olshausenstraße 75, 24118 Kiel, Germany \\ ${ }^{2}$ EcoLab/Campus Ensat, Toulouse INP, Avenue de l'Agrobiopole, 31326 Castanet-Tolosan, France \\ ${ }^{3}$ Instituto Franco-Argentino para el Estudio del Clima y sus Impactos (UMI IFAECI/CNRS-CONICET-UBA) Dpto. de \\ Ciencias de la Atmosfera y los Oceanos, FCEN, Universidad de Buenos Aires Intendente Guiraldes 2160, Ciudad \\ Universitaria (C1428EGA) Ciudad Autónoma de Buenos Aires, Argentina
}

Correspondence: $\quad$ Clemens von Scheffer (cscheffer@ecology.uni-kiel.de)

Relevant dates: $\quad$ Received: 19 December 2018 - Revised: 18 March 2019 - Accepted: 3 April 2019 Published: 8 May 2019

How to cite:

von Scheffer, C., Lange, A., De Vleeschouwer, F., Schrautzer, J., and Unkel, I.: 6200 years of human activities and environmental change in the northern central Alps, E\&G Quaternary Sci. J., 68, 13-28, https://doi.org/10.5194/egqsj-68-13-2019, 2019.

Abstract:

In this study, we combine erosion and anthropogenic proxies ( $\mathrm{Ti}, \mathrm{Pb}$ ) from calibrated portable XRF with pollen and radiocarbon chronologies in peat from mires of the Kleinwalser Valley (Kleinwalsertal, Vorarlberg, Austria) to reconstruct palaeoenvironmental change and human impact in the northern central Alps. Favoured by a wetter climate, two analysed mires formed 6200 years ago in a densely forested valley. Landscape opening suggests that the first anthropogenic impact emerged around 5700 to 5300 cal BP. Contemporaneously, lead enrichment factors (Pb EFs) indicate metallurgical activities, predating the earliest archaeological evidence in the region. Pollen and erosion proxies show that large-scale deforestation and land use by agro-pastoralists took place from the mid- to late Bronze Age (3500 to 2800 cal BP). This period was directly followed by a prominent peak in $\mathrm{Pb} \mathrm{EF}$, pointing to metallurgical activities again. After $200 \mathrm{cal} \mathrm{CE}$, a rising human impact was interrupted by climatic deteriorations in the first half of the 6th century CE, probably linked to the Late Antique Little Ice Age. The use of the characteristic $\mathrm{Pb}$ EF pattern of modern pollution as a time marker allows us to draw conclusions about the last centuries. These saw the influence of the Walser people, arriving in the valley after $1300 \mathrm{calCE}$. Later, the beginning of tourism is reflected in increased erosion signals after 1950 cal CE. Our study demonstrates that prehistoric humans were intensively shaping the Kleinwalser Valley's landscape, well before the arrival of the Walser people. It also demonstrates the importance of palaeoenvironmental multiproxy studies to fill knowledge gaps where archaeological evidence is lacking.

Kurzfassung: $\quad$ In dieser Studie kombinieren wir Paläoproxies für Erosion und menschliche Aktivitäten $(\mathrm{Ti}, \mathrm{Pb})$ aus Messungen eines mobilen RFA- bzw. XRF-Analysators mit Pollen und Radiokohlenstoffdatierungen in Torfproben aus Mooren des Kleinwalsertals (Vorarlberg, Österreich). Auf diese Weise sollen der Wandel der Paläoumweltbedingungen sowie der Einfluss des Menschen auf die Landschaft der nördlichen Zentralalpen untersucht werden. Begünstigt durch feuchteres Klima, begann vor ca. 6200 Jahren im damals dicht bewaldeten Tal die Torfbildung in zwei der untersuchten Moore. Au- 
flichtungen des Waldes deuten auf den ersten menschlichen Einfluss zwischen cal B.P. 5700 und 5300 hin. Gleichzeitig suggerieren Bleianreicherungen $(\mathrm{Pb} \mathrm{EF})$ metallurgische Aktivitäten, die weit vor jeglichen archäologischen Beweisen in der Region liegen. Pollen und Erosionsproxies bezeugen eine weitläufige Entwaldung und Landnutzung durch Landwirtschaft und Beweidung in der mittleren und späten Bronzezeit (3500 bis 2800 cal B.P.). Dieser Phase folgte ein vorläufiger Höchstwert des $\mathrm{Pb}$ EF zum Beginn der Eisenzeit, der erneut auf Bergbau oder Metallurgie in der näheren Umgebung hindeutet. Eine im cal A.D. 3. Jahrhundert einsetzende verstärkte Landnutzung wird im cal A.D. 6. Jahrhundert unvermittelt durch klimatisch ungünstigere Bedingungen unterbrochen, welche der sogenannten spätantiken kleinen Eiszeit zugeschrieben werden können. Unter Zuhilfenahme des charakteristischen Verlaufs der modernen Bleiemissionen als Zeitmarker, konnten die Analyseergebnisse der letzten Jahrhunderte eingeordnet werden. Diese waren von der Ansiedlung der Walser im cal A.D. 14. Jahrhundert geprägt. Nach cal A.D. 1950 zeigt sich außerdem der erstarkende Tourismus anhand höherer Erosionsspuren. Unsere Ergebnisse machen deutlich, dass die Landschaft des Kleinwalsertals schon weit vor Ankunft der Walser vom Menschen genutzt und verändert wurde. Unsere Studie betont zudem die Wichtigkeit der Anwendung unterschiedlicher Paläoproxies, insbesondere, wenn archäologische Anhaltspunkte zur Landnutzungsgeschichte fehlen.

\section{Introduction}

Humans have been recurringly present in Alpine environments since the last deglaciation (e.g. Cornelissen and Reitmaier, 2016). These harsh landscapes are heterogeneous and sensitive to climate (Barry, 2002), which requires specific human adaptation (Clegg et al., 1970). Half nomadic lifestyles or transhumance have been strategies to survive, and are still today the basis for seasonal livestock management practice in mountainous regions (e.g. Reitmaier et al., 2018). There is however no consensus on the human colonisation of European mountains during the Holocene. In the Alps, the onset of human impact is still not fully understood because occupation pulses were radiating from different regions and societies at different time periods (e.g. Bätzing, 2015; Carcaillet, 1998; Dietre et al., 2017; Oeggl and Nicolussi, 2009; Valese et al., 2014). It is therefore important to document human occupation and its impact on mountain environments to a certain level of detail, as each region or each valley reveals pieces of information on the complex spatial linkages between humans and environmental and climatic conditions.

Another challenge in reconstructing past human impacts in the Alps is the general scarcity of suitable palaeoenvironmental archives in high mountain areas. Archaeological records and historical sources cannot provide continuous information and may bias interpretations towards separate findings. These gaps are generally closed by environmental archives, such as trees, lakes, glaciers or mires, which potentially provide uninterrupted records of past environmental changes (anthropogenic or natural). However, except for pollen or dendrochronological studies, mountain mires are so far rarely used as environmental archives.

In this paper, we present a multiproxy study of the Kleinwalser Valley (Kleinwalsertal) in the Austrian northern central Alps, using small mountain mires as environmental archives. The valley is historically known for its human occupation, animal husbandry and forestry only since the Late Middle Ages (Fink and von Klenze, 1891; Wagner, 1950). Before that, the human impact on this valley is unclear. While Romans were present in the Alpine foreland (Mackensen, 1995; Weber, 1995), there are no records of their presence in the valley. Palaeovegetation information suggests prehistoric land use (Dieffenbach-Fries, 1981; GrosseBrauckmann, 2002) but chronologies and data are limited. Other evidence points to early activities at archaeological sites in the valley (Bachnetzer, 2017; Gulisano, 1994, 1995; Leitner, 2003), which are located close to our study sites (Fig. 1). These spots may have acted as strategic points between Alpine foreland and the surrounding mountain ranges, leading prehistoric humans to cross and occupy the Kleinwalser Valley.

By combining geochemical and palynological data together with radiocarbon chronologies, we aim at better understanding the points in time and impacts of human occupation in the Kleinwalser Valley's landscape and beyond. We also aim at detecting early metallurgical activities, possibly where archaeological evidence is lacking. By looking into the past, using multiple proxies on chronologically constrained peat sequences from a key area, we provide new insights into the development and interaction of landscape, climate and humans from mid-Holocene to modern times in the northern central Alps.

\section{Study sites}

The Kleinwalser Valley belongs to the federal state of Vorarlberg in the north-western part of Austria (Fig. 1) and is located at the junction of the geological units of the Northern Calcareous Alps, Penninic flysch and Helvetic (Völk, 2001). The valley floor elevates around $1100 \mathrm{~m}$ a.s.l. and is 
surrounded by mountains ranging from 2000 to $2500 \mathrm{~m}$ a.s.1. Geologically speaking, the watershed is composed of calcareous as well as silicate rocks. During the late Pleistocene, the valley was glaciated (Völk, 2001) and several moraines are still present. Iron $(\mathrm{Fe})$, lead $(\mathrm{Pb})$, zinc $(\mathrm{Zn})$ and copper $(\mathrm{Cu})$ ores are present outside the valley. Within $20 \mathrm{~km} \mathrm{~N}-\mathrm{NE}$, iron had been exploited since $1471 \mathrm{CE}$ in Sonthofen (Merbeler, 1995). $\mathrm{Pb}-\mathrm{Zn}$ deposits are known to the NE at Himmelschrofen (Fig. 1) (von Gümbel, 1861) and in the Ostrach Valley since $1620 \mathrm{cal} \mathrm{CE}$ (Oblinger, 1996). To the south, Zn$\mathrm{Pb}$ deposits exist at $\mathrm{Zug}$, at St. Anton at Arlberg, and at St. Christoph at Arlberg and $\mathrm{Cu}$ can be found at Bartholomäberg (Weber, 1997) within $35 \mathrm{~km}$ off the lower Kleinwalser Valley.

A temperate climate in the Kleinwalser Valley is reflected by a mean annual temperature of $5.7^{\circ} \mathrm{C}$ and $1863 \mathrm{~mm}$ of mean annual precipitation (HDÖ, 1994). In combination with impermeable sediments of glacial or postglacial lacustrine origin, these climate conditions foster the development of many mires in the valley (Schrautzer et al., 2019; El Balti et al., 2017; Völk, 2001).

The main study site, Hoefle Mire (HFL, GPS: $47^{\circ} 21^{\prime} 52.5^{\prime \prime} \mathrm{N}, 10^{\circ} 10^{\prime} 37.2^{\prime \prime} \mathrm{E}$, Fig. 1), is at an elevation of $1020 \mathrm{~m}$ a.s.l. and in immediate proximity of the early Mesolithic archaeological site "Egg" (Bachnetzer, 2017) (Fig. 1a) on a small rise almost in the middle of the valley bottom. Its sheltered position between the rivers Breitach and Schwarzwasser protects it from both river erosion and direct sediment input from the mountainsides. Therefore, this mire is a suitable archive to record atmospheric signals, undisturbed by small-scale processes. The current vegetation consists of typical bog species such as Sphagnum spp., Eriophorum vaginatum and several species of the family Ericaceae. Glacial ground moraine material and localised lake clays form the underlying sediment (Zacher, 1990). Mowing and a drainage ditch, accompanied by a gravelled hiking road, affect the mire at present.

A second study site, the Ladstatt Mire (LAD, GPS: $47^{\circ} 21^{\prime} 28.1^{\prime \prime} \mathrm{N}, 10^{\circ} 09^{\prime} 26.9^{\prime \prime} \mathrm{E}$ ), is situated at a distance of $1.7 \mathrm{~km}$ to the south-west of Hoefle Mire at $1140 \mathrm{~m}$ a.s.l., just at the foot of a forested slope (Küren Valley) to the Gottesacker plateau and downhill of the archaeological site "Schneiderkürenalpe" (Fig. 1b). This slope is characterised by almost no surface runoff. All precipitation disappears into the karstic underground (Goldscheider, 1998). LAD is comparable to HFL in terms of size and surface vegetation, although Sphagnum is more dominant. A road with ditches separates the mire from the valley's slope.

A third peat profile at "Halden-Hochalpe" (HHA, GPS: $47^{\circ} 20^{\prime} 18.3^{\prime \prime} \mathrm{N}, 10^{\circ} 03^{\prime} 49.2^{\prime \prime} \mathrm{E}$ ) (Fig. 1) was only surveyed in 2017. The HHA mire developed on a sediment-filled glacial cirque form (de Graaff et al., 2003) at $1660 \mathrm{~m}$ a.s.l. The uppermost Subersach River meanders through the peatland, which allowed sampling of the bottom of the profile to date the onset of peat formation.

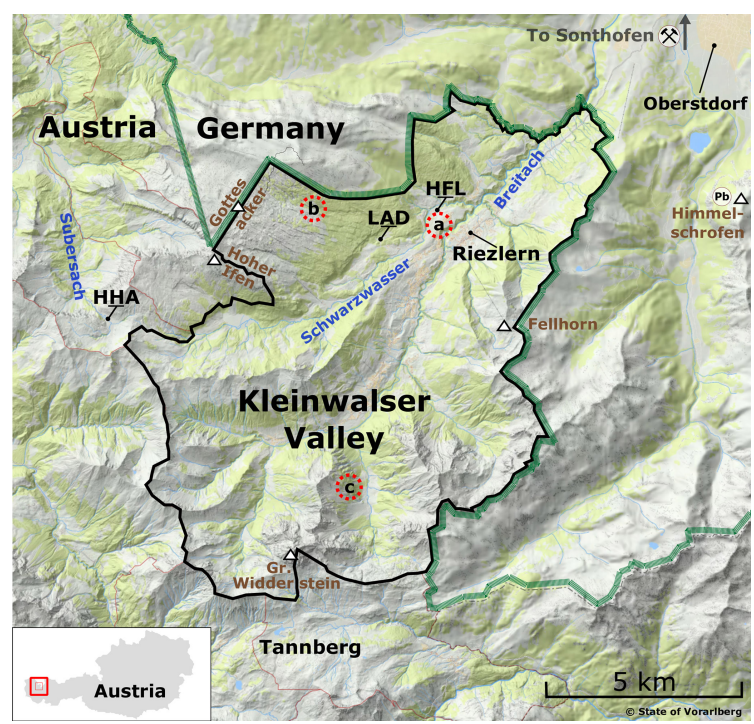

Figure 1. The Kleinwalser Valley and surrounding areas. Archaeological sites (red dotted circles): Egg (a), Schneiderkürenalpe (b), Neolithic flint mine (c). Sampled mire sites: Hoefle Mire (HFL), Ladstatt Mire (LAD), Halden-Hochalpe (HHA). Mountains (white triangles). Modified from data source: state of Vorarlberg - http: //data.vorarlberg.gv.at (last access: 6 October 2018).

\section{Methods}

\subsection{Coring and sampling}

Field sampling was performed in early August 2016 in the centre of HFL. A peat sequence of $240 \mathrm{~cm}$ was recovered in three parallel, overlapping cores (B, C, D) using a Russian peat corer with a chamber of $5 \mathrm{~cm}$ in diameter. Additionally, a $10 \times 10 \times 30 \mathrm{~cm}$ monolith of the topmost part was sampled with a serrated ceramic blade, to avoid compression in the fibrous living part of the acrotelm. Similarly, we recovered an $83 \mathrm{~cm}$ long sediment core and a $28 \mathrm{~cm}$ monolith at LAD. All cores and monoliths were wrapped into cling film, transferred to PVC half-tubes in closed plastic hoses and stored at $3{ }^{\circ} \mathrm{C}$. At HHA, only a charred wood sample was collected for ${ }^{14} \mathrm{C}$ dating, just below the bottom peat layers.

After freezing the cores for $2 \mathrm{~d}$ at $-18^{\circ} \mathrm{C}$, each of the sections was cut into $1 \mathrm{~cm}$ thick slices with a stainless-steel band saw. Subsamples of every slice were cut with ceramic knives, stored in ziplock bags and frozen again. Contamination was minimised following cutting protocols by De Vleeschouwer et al. (2010a) and Givelet et al. (2004). The dimensions of the subsamples dedicated to geochemistry were measured with a Vernier calliper. These were then freeze-dried and weighed to obtain dry bulk density. To cover the gap between the first two core sections in HFL, an overlapping part of core (C) was subsampled and fitted to the main core (B) by using dry bulk density and element concentration profiles. 


\subsection{Radiocarbon dating and chronology}

Sphagnum stems and leaves were selected for radiocarbon dating from fresh samples in ultrapure water. When Sphagnum was absent (in deeper/more decomposed peat layers), other plant remains (Eriophorum spindles, seeds, Ericaceae leaves, wood) as well as bulk peat were selected and sent to Poznan AMS Radiocarbon Laboratory (Poland). The calibrated ages (Table 1) and age-depth models (Fig. 2) were produced in R, version 3.4.2 (R Core Team, 2017), by using the packages clam version 2.3.2 (Blaauw, 2010) and rbacon version 2.3.3 (Blaauw and Christen, 2011). Both packages work with the IntCal13 radiocarbon calibration curve (Reimer et al., 2013). Unless denoted otherwise, ages are given as calibrated before present (cal BP, i.e. years before 1950) for prehistoric times. For a more convenient comparison to historical sources, interpretations for the last 2000 years are made in cal CE. The classification of cultural periods was performed based on the study of Roepke and Krause (2013).

\subsection{Pollen analysis}

A volume of $2 \mathrm{~mL}$ was taken from 14 peat samples of cores HFL-B and HFL-C in the overlapping section and prepared for pollen analysis, following the method described by Moore et al. (1991). The material was pretreated in separate steps in $10 \% \mathrm{HCl}$ and $10 \% \mathrm{KOH}$ to get rid of carbonates and humic substances. Macro remains were removed with a $200 \mu \mathrm{m}$ mesh. The sample was first cooked for $4 \mathrm{~min}$ in a 9:1 solution of acetic anhydride and concentrated sulfuric acid and centrifuged. Particles below $6 \mu \mathrm{m}$ were removed with ultrasonic sieving. The absence of siliciclastic sediment layers in the analysed samples made the use of HF obsolete. Pollen were counted to a sum of 200 tree pollen (excluding Corylus). Fern spores without perine were counted as indeterminate pteridophytes. The counts were compiled with Tilia version 2.0.60 (Grimm, 2018).

\subsection{Geochemistry}

This study concentrated on calcium $(\mathrm{Ca})$, lead $(\mathrm{Pb})$ and titanium (Ti) for interpretation. While Ca can yield information on the trophic state of a mire, Ti can be used as an erosion or human impact proxy (Hölzer and Hölzer, 1998). Pb often originates from anthropogenic sources when it exceeds its natural background (e.g. Weiss et al., 1999). Using portable $\mathrm{X}$-ray fluorescence spectrometry (pXRF) on peat samples in palaeoenvironmental research has rarely been done so far and is hence not well understood, despite some studies that were assessing its general potential (Kalnicky and Singhvi, 2001; Mejía-Piña et al., 2016; Shand and Wendler, 2014; Shuttleworth et al., 2014). Therefore, a regression analysis was conducted to evaluate and calibrate the semi-quantitative $\mathrm{pXRF}$ by several parallel quantitative measurements with inductively coupled plasma mass spectrometry (ICP-MS). In HFL-
B and HFL-C, a total of 187 and 51 samples were selected for pXRF scanning and ICP-MS analyses, respectively. A total of 62 samples were selected from the LAD core for $\mathrm{pXRF}$ scanning. The samples were transferred into Falcon tubes together with eight glass beads $(4 \mathrm{~mm})$ and ground $3 \times 20$ s using a FastPrep-24 ${ }^{\circledR}$ mixer at maximum speed.

Samples dedicated to pXRF were transferred into $12.5 \mathrm{~mL}$ polypropylene vials, closed with Fluxana TF-240-255 film and rubber band. All samples were measured using a Thermo Fisher Niton XL3t pXRF equipped with an Au anode and a $50 \mathrm{kV}$ X-ray tube. The predefined "soil mode" was used with $180 \mathrm{~s}$ of measurement time each for the main and low filter, which is $60 \mathrm{~s}$ above the minimum duration recommended by Shuttleworth et al. (2014). Every sample was measured at least three times and shaken after each scan to control the reproducibility of measurements (precision). In addition to the Certified Reference Materials (CRM) used with ICP-MS (see below), BCR-060 (aquatic plants), IAEA-336 (lichen), IPE176 (reed/Phragmites) and NIST-1575a (pine needles) were scanned. Table 2 shows the quality control of pXRF. Estimated standard sample deviations (SD) based on $n$ repeated measurements remained mostly below or around $10 \%$. Only for Ti, did a higher SD of $18.8 \%$ occur in NJV941. All three elements were above the certified concentrations.

Samples dedicated to ICP-MS were digested using $\mathrm{HNO}_{3}$, $\mathrm{HF}$ and $\mathrm{H}_{2} \mathrm{O}_{2}$ in a class 100 clean room following the protocol of Vanneste et al. (2015). Depending roughly on the dry bulk density of the peat sediment sample, the final aliquots were diluted to total factors between 2500 and 28500 . To verify the analytical quality, precision and accuracy of the ICP-MS results, the CRMs (GBW-07603 bush branches and leaves, NIST-1515 apple leaves, NIST-1547a peach leaves, NJV-941 Carex/sedge peat, NJV-942 Sphagnum peat) were digested and measured along with the samples. Procedural blanks were added to monitor possible contamination or systematic errors. Measurements were performed on an Agilent $7500 \mathrm{CE}$ at Observatoire Midi-Pyrénées, Toulouse, France. The internal ICP-MS calibration with a multi-element standard was run every 10th sample. Measured concentrations were within $11 \%$ of the certified values (Table 3). Only NJV941 deviated more than $10 \%$ for $\mathrm{Ca}$ and $\mathrm{Pb}$.

\section{Results}

\subsection{Age-depth model}

Median ages were extracted from the age-depth model for further interpretation. The accumulation rates for the model of each core were calculated as the median of 1000 estimates by rbacon for each depth. In the lowermost $60 \mathrm{~cm}$ of HFL, an accumulation of almost $0.9 \mathrm{~mm} \mathrm{a}^{-1}$ is observed (Fig. 2), while rates of 0.3 to $0.6 \mathrm{~mm} \mathrm{a}^{-1}$ prevailed up to $37 \mathrm{~cm}$ in depth. The following section of $12 \mathrm{~cm}$ was characterised by a very low accumulation of 0.2 to $0.1 \mathrm{~mm} \mathrm{a}^{-1}$ and comprised almost 900 years. In contrast, accumulation or growth 
Table 1. List of radiocarbon samples including information about origin, depth, dated material, ${ }^{14} \mathrm{C}$ ages and calibrated ages within a $95 \%$ confidence interval (probabilities $<1 \%$ excluded).

\begin{tabular}{|c|c|c|c|c|c|c|}
\hline Lab. no. & Site & Depth $(\mathrm{cm})$ & Material & ${ }^{14} \mathrm{C}$ age $(\mathrm{BP})$ & $\mathrm{Cal}$ age (BP) & Comment \\
\hline Poz-101727 & HFL & 21.3 & $\begin{array}{l}\text { Sphagnum stems } \\
\text { and leaves, few } \\
\text { Eriophorum spindles }\end{array}$ & $127 \pm 0.35 \mathrm{pMC}$ & $\begin{array}{l}-32 \text { to }-29.9(80.8 \%) \\
-12.1 \text { to }-12(4.2 \%) \\
-9.7 \text { to }-9.4(10 \%)\end{array}$ & \\
\hline Poz-104865 & HFL & 29.9 & $\begin{array}{l}\text { Eriophorum spindles, } \\
\text { Sphagnum stems } \\
\text { and leaves }\end{array}$ & $65 \pm 30$ & $\begin{array}{l}31-138(71.4 \%) \\
222-257(23.5 \%)\end{array}$ & $0.5 \mathrm{mg} \mathrm{C}$ \\
\hline Poz-92252 & HFL & 36.0 & Eriophorum spindles & $1110 \pm 30$ & $\begin{array}{l}939-959(1.4 \%) \\
951-1071(93.5 \%)\end{array}$ & $0.7 \mathrm{mg} \mathrm{C}$ \\
\hline Poz-101728 & HFL & 48.3 & $\begin{array}{l}\text { Sphagnum stems } \\
\text { and leaves, } \\
\text { Eriophorum spindles }\end{array}$ & $1525 \pm 30$ & $\begin{array}{l}1348-1424(55.6 \%) \\
1428-1444(4.3 \%) \\
1454-1522(34.9 \%)\end{array}$ & \\
\hline Poz-92255 & HFL & 80.0 & Sphagnum leaves & $2410 \pm 30$ & $\begin{array}{l}2351-2496(81.2 \%) \\
2596-2612(2.9 \%) \\
2637-2684(10.9 \%)\end{array}$ & \\
\hline Poz-92251 & HFL & 120.3 & $\begin{array}{l}\text { Sphagnum stem, } \\
\text { Eriophorum remains }\end{array}$ & $3065 \pm 35$ & $\begin{array}{l}3180-3200(4.6 \%) \\
3206-3363(90.4 \%)\end{array}$ & \\
\hline Poz-86728 & HFL & 152.0 & Bulk peat & $4105 \pm 35$ & $\begin{array}{l}4453-4461(1 \%) \\
4521-4713(70.5 \%) \\
4753-4814(22.7 \%)\end{array}$ & \\
\hline Poz-96113 & HFL & 176.7 & $\begin{array}{l}\text { Wood and Eriophorum } \\
\text { remains, }\end{array}$ & $4710 \pm 40$ & $\begin{array}{l}5322-5419(46.4 \%) \\
5439-5486(20.8 \%) \\
5507-5581(27.6 \%)\end{array}$ & \\
\hline Poz-92253 & HFL & 202.0 & $\begin{array}{l}\text { Ligneous material, } \\
\text { wood }\end{array}$ & $2730 \pm 35$ & $\begin{array}{l}2759-2883(93.5 \%) \\
2911-2918(1.5 \%)\end{array}$ & $\begin{array}{l}\text { Excluded outlier, } \\
0.2 \mathrm{mg} \mathrm{C}\end{array}$ \\
\hline Poz-86726 & HFL & 235.0 & Wood & $5330 \pm 40$ & $\begin{array}{l}5996-6208(93.9 \%) \\
5254-6260(1 \%)\end{array}$ & \\
\hline Poz-86729 & HFL & 175.0 & Bulk peat & $4400 \pm 35$ & $\begin{array}{l}4860-5054(91 \%) \\
5190-5256(3.3 \%)\end{array}$ & Core D \\
\hline Poz-95963 & HHA & $\sim 145.0$ & $\begin{array}{l}\text { Charred wood, tree age } \\
\text { outer age ring, } \\
>50\end{array}$ & $3195 \pm 35$ & $\begin{array}{l}3357-3479 \\
(94.8 \%)\end{array}$ & \\
\hline Poz-99319 & LAD & 24.8 & $\begin{array}{l}\text { Sphagnum stems } \\
\text { and leaves }\end{array}$ & $127.74 \pm 0.37 \mathrm{pMC}$ & $\begin{array}{l}-32 \text { to }-29.3(81.9 \%) \\
-12.1 \text { to }-12(5.8 \%) \\
-9.7 \text { to }-9.4(7.3)\end{array}$ & $0.7 \mathrm{mg} \mathrm{C}$ \\
\hline Poz-103202 & LAD & 31.2 & $\begin{array}{l}\text { Eriophorum } \\
\text { spindles }\end{array}$ & $40 \pm 30$ & $\begin{array}{l}-5 \text { to } 2(6.9 \%) \\
32-83(52.1 \%) \\
97-108(3 \%) \\
112-137(13.8 \%) \\
223-255(19 \%)\end{array}$ & $0.8 \mathrm{mg} \mathrm{C}$ \\
\hline Poz-99198 & LAD & 63.5 & Eriophorum spindles & $3185 \pm 35$ & $2253-3475(95 \%)$ & \\
\hline Poz-86730 & LAD & 102.5 & Bulk peat & $5320 \pm 40$ & $\begin{array}{l}5991-6210(93.5 \%) \\
6250-6262(1.5 \%)\end{array}$ & \\
\hline
\end{tabular}


Table 2. Repeated pXRF measurements $(n)$ of $\mathrm{Ca}, \mathrm{Pb}$ and Ti versus certified (Cert.) concentrations in organic Certified Reference Materials (CRM). Sample standard deviations (SDs) from certified values as a percentage.

\begin{tabular}{lrrrr|rrrr|rrrr}
\hline Element & \multicolumn{3}{c}{$\mathrm{Ca}$} & \multicolumn{4}{c}{$\mathrm{Pb}$} & \multicolumn{4}{c}{ Ti } \\
\cline { 2 - 10 } Ualue & $\begin{array}{r}\text { Cert. } \\
\left(\mathrm{m} \mathrm{kg}^{-1}\right)\end{array}$ & $\begin{array}{r}\mathrm{pXRF} \\
\left(\mathrm{m} \mathrm{kg}^{-1}\right)\end{array}$ & $\begin{array}{r}\mathrm{SD} \\
(\%)\end{array}$ & $n$ & $\begin{array}{r}\text { Cert. } \\
\left(\mathrm{mg} \mathrm{kg}^{1}\right)\end{array}$ & $\begin{array}{r}\mathrm{pXRF} \\
\left(\mathrm{mg} \mathrm{kg}^{-1}\right)\end{array}$ & $\begin{array}{r}\text { SD } \\
(\%)\end{array}$ & $\begin{array}{r}\text { Cert. } \\
\left(\mathrm{mg} \mathrm{kg}^{1}\right)\end{array}$ & $\begin{array}{r}\mathrm{pXRF} \\
\left(\mathrm{mg} \mathrm{kg}^{-1}\right)\end{array}$ & $\begin{array}{r}\text { SD } \\
(\%)\end{array}$ & $n$ \\
\hline BCR060 & - & 54013 & 2.0 & 8 & 64 & 92.5 & 4.3 & 8 & - & 280.5 & 11.6 & 8 \\
GBW07603 & 16800 & 42761 & 0.4 & 5 & 47 & 73.7 & 3.0 & 5 & 95 & 214.4 & 4.1 & 5 \\
IAEA336 & - & 8262 & 5.2 & 4 & 4.9 & 6.2 & 10.1 & 4 & - & 219.6 & 6.0 & 4 \\
IPE176 & 4160 & 8736 & 6.1 & 5 & 8.24 & 13.4 & 8.7 & 5 & - & 1172.5 & 6.8 & 5 \\
NIST1515 & 15260 & 44634 & 1.9 & 3 & 0.47 & - & - & - & - & 15.9 & - & 1 \\
NIST1547a & 15600 & 41795 & 0.1 & 3 & 0.87 & - & - & - & - & 18.7 & 0.1 & 2 \\
NIST1575a & 2500 & 8882 & 0.3 & 3 & 0.167 & - & - & - & - & 15.3 & 12.4 & 2 \\
fNJV941 & 10200 & 33937 & 4.4 & 8 & 2.4 & 2.3 & 10.8 & 8 & - & 64.1 & 18.8 & 8 \\
NJV942 & 1200 & 4024 & 2.5 & 6 & 10.1 & 14.3 & 3.4 & 6 & - & 262.0 & 2.9 & 6 \\
\hline
\end{tabular}

Table 3. Quality control of $\mathrm{Ca}$, Ti and $\mathrm{Pb}$. Measurements by ICP-MS of procedural blanks and in organic Certified Reference Materials (CRM). Total deviations (Dev.) from certified values as a percentage.

\begin{tabular}{lrrr|rrr|rrr}
\hline & \multicolumn{3}{c}{$\mathrm{Ca}$} & \multicolumn{2}{c}{$\mathrm{Ti}$} & \multicolumn{3}{c}{$\mathrm{Pb}$} \\
\cline { 2 - 10 } CRM/blank & Cert. & ICP-MS & Dev. & Cert. & ICP-MS & Dev. & Cert. & ICP-MS & Dev. \\
\hline & $\left(\mathrm{mg} \mathrm{kg}^{-1}\right)$ & $\left(\mathrm{mg} \mathrm{kg}^{-1}\right)$ & $(\%)$ & $\left(\mathrm{mg} \mathrm{kg}^{-1}\right)$ & $\left(\mathrm{mg} \mathrm{kg}^{-1}\right)$ & $(\%)$ & $\left(\mathrm{mg} \mathrm{kg}^{-1}\right)$ & $\left(\mathrm{mg} \mathrm{kg}^{-1}\right)$ & $(\%)$ \\
\hline Blank 1 & - & 0.03 & - & - & 0.000 & - & - & 0.000 & - \\
Blank 2 & - & 0.01 & - & - & 0.000 & - & - & 0.000 & - \\
Blank 3 & - & 0.01 & - & - & 0.000 & - & - & 0.000 & - \\
NIST1515 (a) & 15250 & 14216 & -6.8 & - & 13.3 & - & 0.47 & 0.44 & -5.7 \\
NIST1515 (b) & 15250 & 13900 & -8.8 & - & 12.4 & - & 0.47 & 0.49 & 3.7 \\
GBW07603 (a) & 16800 & 16143 & -3.9 & 95 & 92.1 & -3.0 & 47 & 47.32 & 0.7 \\
GBW07603 (b) & 16800 & 16696 & -0.6 & 95 & 90.2 & -5.1 & 47 & 48.60 & 3.4 \\
NJV941 (a) & 10200 & 8766 & -14.1 & - & 34.5 & - & 2.4 & 2.09 & -13.1 \\
NJV941 (b) & 10200 & 8743 & -14.3 & - & 33.6 & - & 2.4 & 2.11 & -11.9 \\
NJV941 (c) & 10200 & 8689 & -14.8 & - & 27.1 & - & 2.4 & 2.10 & -12.6 \\
NJV942 (a) & 1200 & 1262 & 5.2 & - & 51.8 & - & 10.1 & 9.48 & -6.1 \\
NJV942 (b) & 1200 & 1232 & 2.7 & - & 115.2 & - & 10.1 & 9.13 & -9.6 \\
NJV942 (c) & 1200 & 1181 & -1.6 & - & 49.6 & - & 10.1 & 9.48 & -6.2 \\
NIST1547a & 15600 & 14652 & -6.1 & - & 24.1 & - & 0.87 & 0.86 & -1.1 \\
\hline
\end{tabular}

rates of the topmost layers reached a maximum of more than $8 \mathrm{~mm} \mathrm{a}^{-1}$. The age-depth model of LAD (Fig. 2) had a net accumulation rate of only $0.15 \mathrm{~mm} \mathrm{a}^{-1}$. However, the model is less constrained than in HFL, with a modern age at $25 \mathrm{~cm}$ in depth and $3450 \mathrm{cal} \mathrm{BP}$ at $62 \mathrm{~cm}$ in depth. Especially in the uppermost $30 \mathrm{~cm}$, peat growth took a development similar to HFL, with accumulation or growth rates reaching $9 \mathrm{~mm} \mathrm{a}^{-1}$.

\subsection{Pollen profile}

A detailed interpretation of the pollen record from HFL Mire (Fig. 3) is provided in the discussion below. We can, however, point out major changes in the pollen profile. The deepest part was strongly characterised by Picea pollen. A significant change is observed between 200 and $175 \mathrm{~cm}(5700$ to $5300 \mathrm{cal} \mathrm{BP}$ ) when deciduous forest pollen and herbs ap- peared. After tree pollen were dominating again at $140 \mathrm{~cm}$ $(4000 \mathrm{cal} \mathrm{BP})$, the sudden and strong signals of Poaceae, herbs and cultural plants illustrate a diversification in the spectrum between 125 and $115 \mathrm{~cm}(3450$ to $3150 \mathrm{cal} \mathrm{BP})$. The opposite trend started above, although the overall pattern did not return to a complete dominance of tree pollen. Only in the uppermost $37 \mathrm{~cm}$ (1000 calCE), did Poaceae, herbs and cultural plants represent a larger proportion of the spectrum once again. In order to facilitate the interpretation of palynological data in the discussion, we have assembled pollen into six groups (Fig. 3): 1 - cultural and pastoral; 2 open grassland; 3 - herbs and heather; 4 - forest border; 5 swamp/wetland; 6 - ferns. 

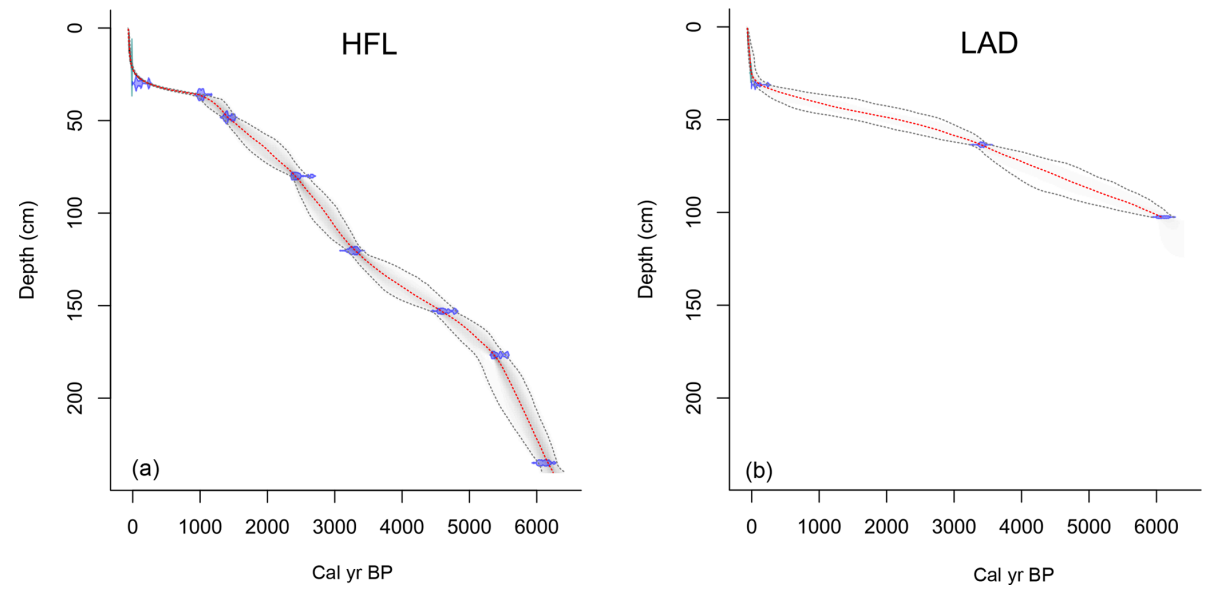

Figure 2. Age-depth models of Hoefle Mire (a) and Ladstatt Mire (b). The median is plotted as a red dotted line amidst the confidence range of $95 \%$ in grey.

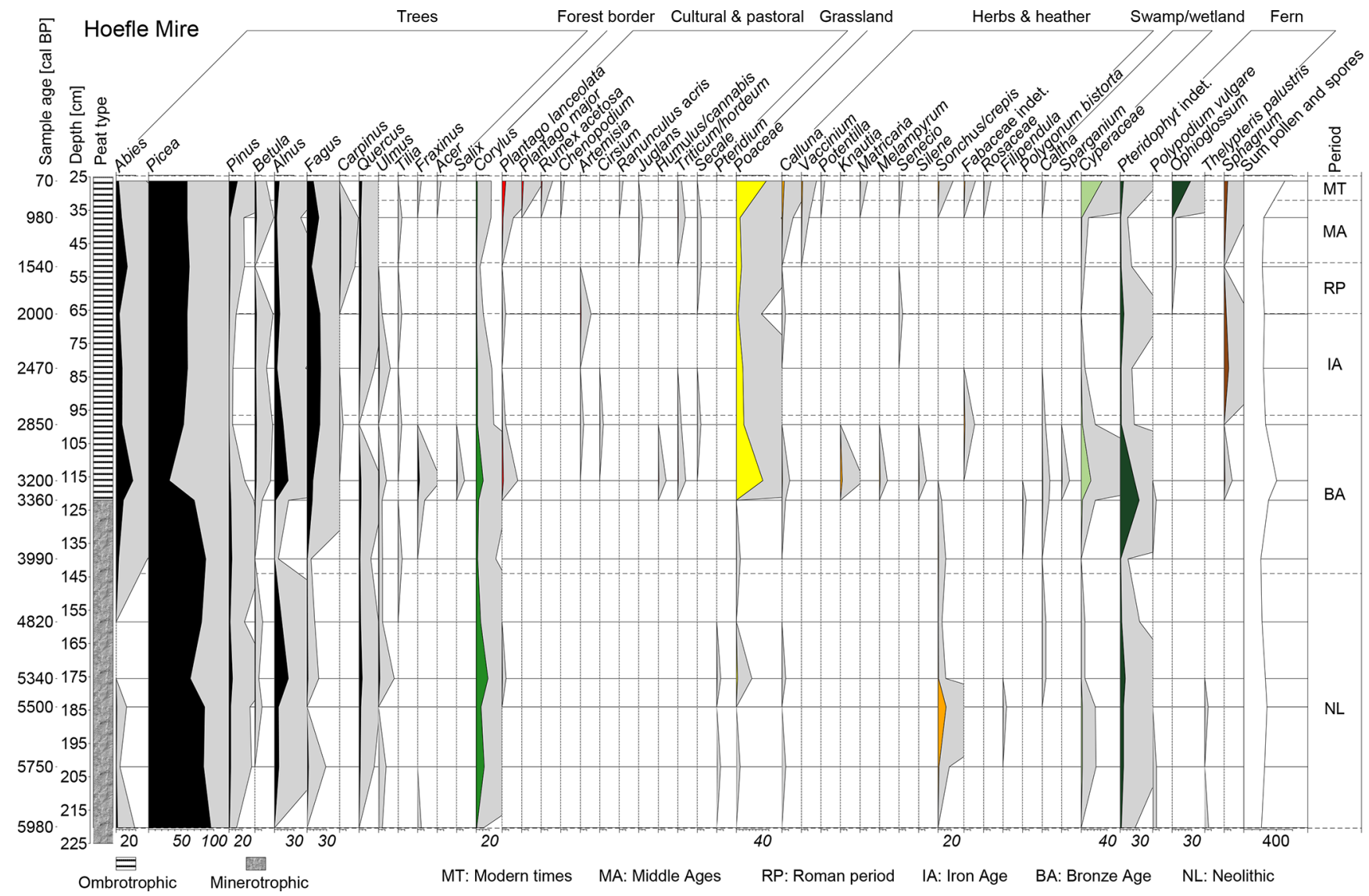

Figure 3. Pollen diagram of HFL Mire. Fully coloured profiles represent pollen percentages, shaded areas enhanced by factor 12. Black: trees; green: forest border (Corylus); yellow: open grassland (Poaceae); red: cultural and pastoral indicators; orange: herbs and heather; light green: swamp/wetland; dark green: fern; brown: Sphagnum; white: total spores and pollen. Vertical lines depict calibrated sample ages. Vertical dashed lines are boundaries of cultural periods. 


\subsection{Geochemistry}

The quantitative and validated ICP-MS results of HFL were compared to the pXRF scans of the same sample, which allowed us to constrain our calibration. The regression analysis in the HFL peat samples showed high adjusted $R^{2}$ values or coefficient of determination $\left(R^{2}\right)$, as a measure for the fit of the model $\left(R_{\mathrm{Ca}}^{2}=0.95, R_{\mathrm{Ti}}^{2}=0.97, R_{\mathrm{Pb}}^{2}=0.99\right.$, Fig. 2). As the two deepest samples $(240-230 \mathrm{~cm})$ were composed of sediment and not peat, they plotted as outliers and were excluded. In the range of measured ICP-MS concentrations (Ca: 2000-14 000, Pb: 2-110 and Ti: $25-400 \mathrm{mg} \mathrm{kg}^{-1}$ ), pXRF values were generally higher than the concentrations obtained by ICP-MS. Transfer functions were therefore calculated to calibrate the pXRF scans of all 187 samples (Fig. 4).

The element-specific overestimation of the pXRF output illustrates that this method cannot be used to quantify element concentrations in peat without a cross-calibration against quantitative methods. Specification and type of sample need to be considered during such a calibration. Shuttleworth et al. (2014) used a Niton XL3t with an Ag anode to evaluate the applicability of $\mathrm{pXRF}$ for $\mathrm{Pb}$ contents in peat. Their results suggested a linear relationship between pXRF and ICP-OES (optical emission spectrometry), which was confirmed in this study. However, their observed overestimation by pXRF was much lower and was attributed to an incomplete $\mathrm{Pb}$ extraction with aqua regia. As a complete digestion was performed in this study, the overestimation by $\mathrm{pXRF}$ for $\mathrm{Pb}$ cannot have a similar explanation. Additionally, the high content of light organic matter in peat should rather result in an underestimation of heavier elements in XRF analysis (Löwemark et al., 2011). Nevertheless, the regression analysis allowed us to generate quantitative results of $\mathrm{Ca}, \mathrm{Pb}$ and $\mathrm{Ti}$ in both minerotrophic and ombrotrophic peat. The only exception was the measurement of mineralrich bottom layer samples with a high element load, which plotted outside the linear regression.

The $\mathrm{Pb}$ enrichment factor $(\mathrm{Pb} \mathrm{EF})$ was calculated following (Weiss et al., 1999) using Ti as a conservative element, which is not affected by dissolution in acidic environments (Nesbitt and Markovics, 1997).

Here we used the background $\mathrm{Pb} / \mathrm{Ti}$ ratio of the bottom sediment, measured by ICP-MS (0.0037), which is close to the generally used upper continental crust (UCC) value (0.004) from McLennan (2001). It is explained by the local geology consisting of limestone, marl and sandstone, resulting in a mixed weathering product.

$\mathrm{PbEF}=\frac{(\mathrm{Pb} / \mathrm{Ti})_{\text {sample }}}{(\mathrm{Pb} / \mathrm{Ti})_{\text {background }}}$

Titanium originates from natural local erosion/sources and is therefore used as a human-impact proxy. Following Shotyk et al. (2002), we calculated a mineral accumulation rate (MAR) on the mires' surfaces in $\mathrm{g} \mathrm{m}^{-2} \mathrm{a}^{-1}$ with a Ti (UCC) of $0.41 \%$ :

$\operatorname{MAR}=100 / 0.41 \times \mathrm{Ti} \times \delta \times \mathrm{pa}$,

where $\delta$ is the dry bulk density and pa is the peat accumulation rate.

The temporal variability of $\mathrm{Ca}, \mathrm{Pb} \mathrm{EF}$ and MAR shown in Fig. 5 is based on the calibrated pXRF concentrations, calibrated ages, densities and accumulation rates (tables in Supplement). Ca concentrations in HFL constantly declined towards the top. After a max. of $15000 \mathrm{mg} \mathrm{kg}^{-1}$ in the deepest peat layers $(6000 \mathrm{cal} \mathrm{BP})$, they fell permanently below $6000 \mathrm{mg} \mathrm{kg}^{-1}$ after $122 \mathrm{~cm}$ (3250 cal BP). Above $62 \mathrm{~cm}$ (1950 cal BP) they decreased to a level below $3000 \mathrm{mg} \mathrm{kg}^{-1}$.

The concentrations of $\mathrm{Ti}$ in HFL decreased from 1040 to around $50 \mathrm{mg} \mathrm{kg}^{-1}$ in the deepest $12 \mathrm{~cm}$ of the core (6250 to $6000 \mathrm{cal} \mathrm{BP})$ and remained low until an increasing trend started above $133 \mathrm{~cm}(3700 \mathrm{cal} \mathrm{BP})$, which culminated at $122 \mathrm{~cm}$ ( $3250 \mathrm{cal} \mathrm{BP})$ with over $385 \mathrm{mg} \mathrm{kg}^{-1}$. Although higher than in the lower half of the profile, concentrations returned to values between 40 and $110 \mathrm{mg} \mathrm{kg}^{-1}$ until an increasing trend, which was shortly interrupted around $48 \mathrm{~cm}$ $(500 \mathrm{calCE})$, started above $58 \mathrm{~cm}(200 \mathrm{calCE})$. This trend turned after reaching $360 \mathrm{mg} \mathrm{kg}^{-1}$ at $32 \mathrm{~cm}(1500 \mathrm{calCE})$ and ultimately came to a halt at the surface.

Excluding the deepest samples of HFL, $\mathrm{Pb}$ was below the detection limit from 230 to $190 \mathrm{~cm}(6250$ to $5600 \mathrm{cal} \mathrm{BP})$ and did not exceed $9 \mathrm{mg} \mathrm{kg}^{-1}$ until $98 \mathrm{~cm}$ in depth. From 97 to $91 \mathrm{~cm}$ ( 2800 to $2650 \mathrm{cal} \mathrm{BP}$ ), concentrations rose to values around $25 \mathrm{mg} \mathrm{kg}^{-1}$. From then on, $\mathrm{Pb}$ oscillated around $15 \mathrm{mg} \mathrm{kg}^{-1}$ until it increased between 50 and $20 \mathrm{~cm}$ (500 to $1970 \mathrm{cal} C E)$ to a maximum of $115 \mathrm{mg} \mathrm{kg}^{-1}$. Thereafter, the profile sharply dropped to $6 \mathrm{mg} \mathrm{kg}^{-1}$ within the next $7 \mathrm{~cm}$ and fell below the detection limit at the subsurface.

In the LAD core, $\mathrm{Ti}$ concentrations were above $1000 \mathrm{mg} \mathrm{kg}^{-1}$ until $85 \mathrm{~cm}$ in depth $(4900 \mathrm{cal} \mathrm{BP})$ and briefly dropped to $200 \mathrm{mg} \mathrm{kg}^{-1}$ at $78 \mathrm{~cm}$ (4800 cal BP). A peak, exceeding $1000 \mathrm{mg} \mathrm{kg}^{-1}$, appeared at $61 \mathrm{~cm}(3200 \mathrm{cal} \mathrm{BP})$, after which the profile stayed slightly below $600 \mathrm{mg} \mathrm{kg}^{-1}$. The concentrations decreased from $34 \mathrm{~cm}$ to $20 \mathrm{~cm}$ in depth (1700-1982 CE) and continued to less than $30 \mathrm{mg} \mathrm{kg}^{-1}$ at the surface.

\section{Discussion}

\subsection{Mire formation}

Peat formation in HFL and LAD began around $6200 \mathrm{cal}$ BP. Pollen proportions suggest a Picea swamp in a densely forested valley at $6000 \mathrm{cal} \mathrm{BP}$, fitting well to the findings of Dieffenbach-Fries (1981). For the same period, other studies reported a wetter and colder climate in the central Alps (Haas et al., 1998; Van der Knaap et al., 2004; Wurth et al., 2004). The fine clayey sediment of a glacial till followed by gyttja at the bottom of both HFL and LAD indicates standing water 
$\mathrm{Ti}$

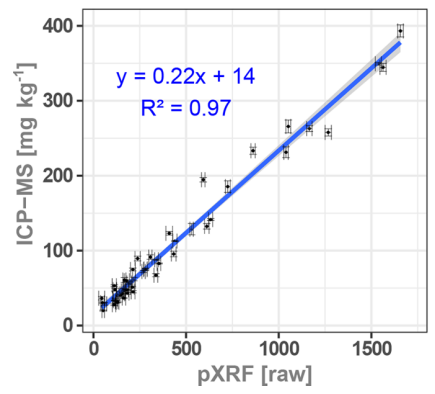

$\mathrm{Pb}$

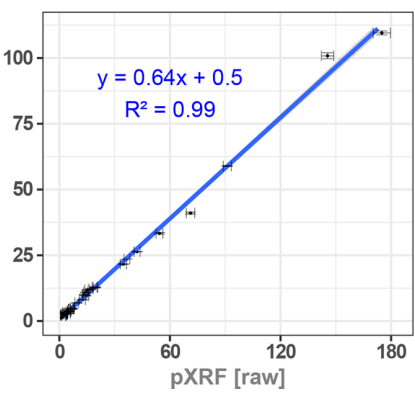

$\mathrm{Ca}$

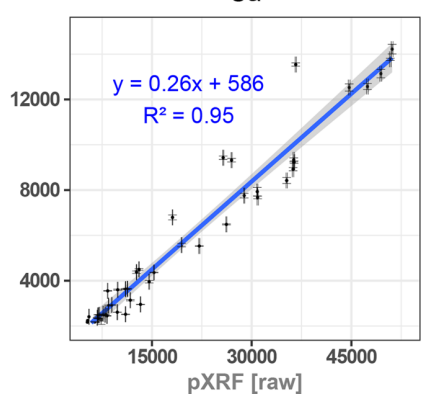

Figure 4. Cross-plots of measured concentrations of $\mathrm{Ca}$, Ti and $\mathrm{Pb}$ with ICP-MS $\left(\mathrm{mg} \mathrm{kg}^{-1}\right)$ versus measured values with $\mathrm{pXRF}$ (raw) for regression analyses.

conditions, which favoured peat formation. Land- or rockslides in the watershed (Schmidt-Thomé, 1960; Völk, 2001) could have resulted from a wetter climate as well and may have reorganised the valley's hydrology, which is very complex (Goldscheider, 1998). This could have further promoted mire formation in certain places, as suggested by GrosseBrauckmann (2002).

\subsection{0 to 3500 cal BP: early human occupation}

Only very little archaeological evidence suggests early human occupation in the area (Bachnetzer, 2017; Leitner, 2003). Similarly, little palaeoecological evidence exists on early local land use. Regional studies showed evidence for fire practices (Clark et al., 1989) and crop cultivation around Lake Constance (Jacomet, 2009; Rösch, 1992) and at Oberstdorf, north of the valley (Fig. 1) (Dieffenbach-Fries, 1981). In HFL, increasing Poaceae pollen and the presence of Plantago as well as the emergence of Corylus suggest anthropogenic landscape opening around $5550 \mathrm{cal} \mathrm{BP}$. This interpretation is further strengthened by a significantly elevated erosion signal (MAR) in HFL. Prehistoric fire practices in the valley can be inferred from the presence of Pteridium and Calluna. While not dendrochronologically dated, a charred tree trunk was pierced (horizontally) at parallel depth in the parallel HFL-D core (not analysed in detail). Although the cause of this fire (anthropogenic or natural) cannot be deciphered, it supports the other indicators in suggesting prehistoric patchy land clearances, possibly for livestock grazing.

Almost simultaneously to the observed pollen signals in $\mathrm{HFL}$, the $\mathrm{Pb}$ EF rose significantly to 50 at $5450 \mathrm{cal} \mathrm{BP}$ and remained around an average value of 22 until $3500 \mathrm{cal} B P$. While this elevated $\mathrm{Pb}$ EF period falls in the minerotrophic part of the core, several authors showed that $\mathrm{Pb}$, an immobile element, could carefully be used as an anthropogenic indicator in minerotrophic peat (e.g. Baron et al., 2005; Shotyk et al., 2001). Archaeological evidence shows that metal tools were circulating in the central Alps (e.g. Artioli et al., 2017). Metallurgy was dominated by $\mathrm{Cu}$ at that time, but $\mathrm{Pb}$ can be present as an impurity (Höppner et al., 2005; Lutz and

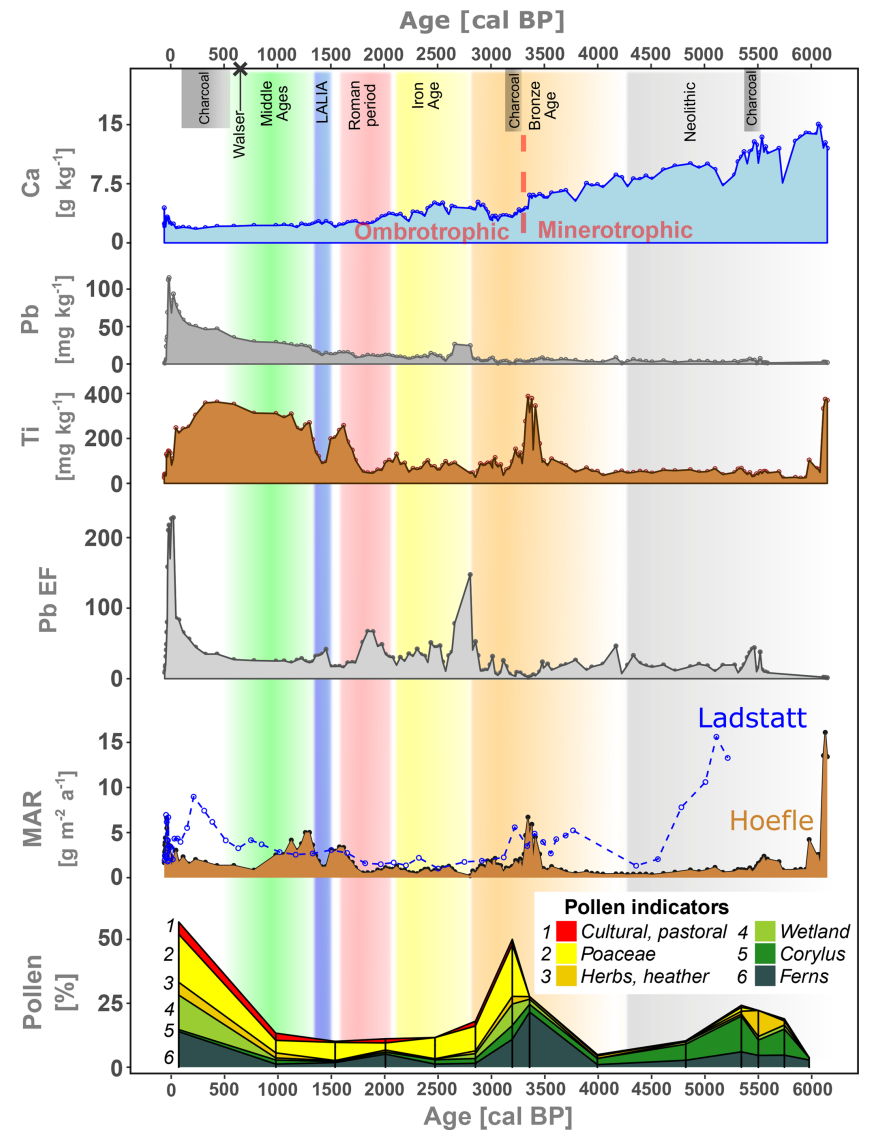

Figure 5. Chronological profile of $\mathrm{Ca}, \mathrm{Pb}$ and $\mathrm{Ti}$ concentrations in $\mathrm{HFL}, \mathrm{Pb}$ EF in HFL, and mineral accumulation rates $\left(\mathrm{g} \mathrm{m}^{-2} \mathrm{a}^{-1}\right)$ in HFL and LAD. Pollen groups as a percentage of total pollen $(\%)$ in HFL. Colours of shaded areas represent cultural periods in the northern central Alps: grey - Neolithic; orange - Bronze Age; yellow - Iron Age; red - Roman period; green - Middle Ages.

Pernicka, 2013). Despite the existence of different ore deposits in the region (see Sect. 2), archaeological evidence suggests that the closest and earliest copper mining emerged in the Lower Inn Valley in the early to mid-Bronze Age around $3600 \mathrm{cal} \mathrm{BP}$ (Breitenlechner et al., 2013; O'Brien, 
2015; Tomedi et al., 2013). Our HFL record strongly suggests that metallurgical activities around the Kleinwalser Valley could have already taken place around $5500 \mathrm{cal} \mathrm{BP}$, which would be almost 2000 years earlier. Our findings are, however, in agreement with other studies, which indicate that Alpine metallurgy started well before $5000 \mathrm{cal}$ BP (Bartelheim et al., 2002; Frank and Pernicka, 2012; Höppner et al., 2005).

\subsection{0 to 2800 cal BP: Bronze Age}

The start of this period saw the evolution from minerotrophic to ombrotrophic conditions in HFL, characterised by the occurrence of Sphagnum and a stabilisation of Ca values, which suggests an independence from bottom sediment influence. The landscape opened, as shown by the emergence of Poaceae, Cyperaceae and Corylus, while tree pollen sank below $50 \%$. Moreover Calluna, Plantago, cereals and other cultural indicators (Triticum/Hordeum, Humulus/Cannabis) support the interpretation of a landscape opening with human presence. A drastic MAR peak in HFL and LAD (Fig. 5) suggests that deforestation and openness strongly promoted soil and slope erosion between 3500 and $3200 \mathrm{cal} \mathrm{BP}$. A bottom layer of partly charred wood debris at HHA was dated to $3360-3480 \mathrm{cal} \mathrm{BP}$, which points to deforestation by fire and further supports land openness. Archaeological evidence from Schneiderkürenalpe (Fig. 1) also suggests pastoral activities in the valley (Leitner, 2003), which would have promoted soil erosion on the karstic western slopes. On the same slopes, a speleothem record from the Hölloch cave (Wurth et al., 2004) showed a contemporary negative $\delta^{13} \mathrm{C}$ excursion, which could have been caused by an enhanced input of soilderived carbon. Cultural pollen indicators and pastoral weeds were observed locally by Dieffenbach-Fries (1981), while Walde and Oeggl (2004) documented fire clearings in the Tannberg area (Fig. 1) between 3600 and 3300 cal BP. Several lake and mire records showed an increasing human impact on the central Alp's landscape during that period (Festi et al., 2014; Schmidl and Oeggl, 2005; Vorren et al., 1993; Wick and Tinner, 1997). Contemporaneously, settlement patterns changed after $3500 \mathrm{cal} \mathrm{BP}$ as a result of climatic deteriorations and new sites appeared at higher elevations in the central Alps (Della Casa, 2013). The same author saw technical and agricultural innovations as a driver of higher impact during the middle to late Bronze Age. In terms of climate, a trend to wetter and colder conditions began after approximately $3300 \mathrm{cal}$ BP (Hormes et al., 2001; Ivy-Ochs et al., 2009; Magny et al., 2009; Vorren et al., 1993), which could have promoted such erosive events by both descending the timberline and bringing more precipitation on an open landscape. While some studies suggested that warmer conditions can promote human activities (Tinner et al., 2003; Vorren et al., 1993), our pollen record does not allow conclusions about warmer or colder conditions. We can however argue that the large erosive event observed in the Kleinwalser Valley and the specific cultural pollen assemblage were a direct consequence of a strong and deliberate human land use rather than being the direct result of climate factors.

\section{$5.42800 \mathrm{cal} \mathrm{BP}$ to $600 \mathrm{cal} \mathrm{CE}$ : Iron Age and Roman period}

The pressure of agro-pastoralism progressively disappeared from 2800 to $2500 \mathrm{cal} \mathrm{BP}$ as shown by the disappearance of Artemisia, Fabacea, Cirsium and Plantago. Cerealia pollen (Hordeum/Triticum and Secale) also go missing around 2500 cal BP. Forests progressively recovered in a stable landscape with minimum erosion, as also reflected in the low MAR. The decreasing human impact in the Kleinwalser Valley after the late Bronze Age may have been triggered by a cold phase (Ivy-Ochs et al., 2009), making harsh mountain environments less attractive. However, several studies discussed or contested a climate-deterministic view on the widespread decline of human activities around this period (e.g. Armit et al., 2014; Röpke et al., 2011; Tinner et al., 2003). Decreasing cultural indicators during this period were also documented elsewhere in the central Alps (Vorren et al., 1993). Yet, a general decline contrasts with human impact in the neighbouring Tannberg area (Walde and Oeggl, 2003, 2004). Why human impact in the Kleinwalser Valley decreased therefore remains unclear at this stage. We can however hypothesise that humans never abandoned the valley completely. The favourable warm and dry period starting around $2000 \mathrm{cal} \mathrm{BP}$ (Büntgen et al., 2011) attracted people again for hunting and pastoralism as suggested by pollen (Artemisia, Plantago) and by archaeological evidence (Leitner, 2003).

While anthropogenic impact in the Kleinwalser Valley declined from 2800 to $2000 \mathrm{cal} \mathrm{BP}, \mathrm{Pb}$ EF suggests that metallurgical activities continued in the area. $\mathrm{A} \mathrm{Pb} \mathrm{EF}$ of up to 175 hints at intensive metallurgical activities not far from HFL between 2800 and 2600 cal BP. The exact locations of these activities remain unclear, but may be local to regional, as metallurgy became widespread in the eastern Alps around 3500 cal BP (Höppner et al., 2005; Lutz and Pernicka, 2013). The signal is in line with the technological introduction of the first $\mathrm{Pb}$ alloys (Tomedi et al., 2013). Afterwards (26002300 cal BP), short episodes of moderate Pb EF indicate ongoing metallurgy in the region. Part of it could have been connected to Celtic cultures (e.g. La Tène), as metal artefacts and metallurgy evidence were found in the northern central Alps (Bächtiger, 1982; Mansel, 1989).

During early Roman times (ca. 2000 cal BP in this region) HFL and LAD show a low MAR, indicating little erosion and therefore decreased land use, as Walde and Oeggl (2003, 2004) already suggested. In contrast, Friedmann and Stojakowits (2017) reported higher land use in the Alpine foreland. Later on, the study of Büntgen et al. (2011) suggested warm summers with moderately low precipitation from 200 to $300 \mathrm{cal}$ CE. Simultaneously, rising mineral input in HFL 
indicates increased land use in the Kleinwalser Valley. The local and regional human activity and connectivity of the valley can only be inferred by connecting historical sources (Dertsch, 1974; Fink and von Klenze, 1891; von Raiser, 1830; Weber, 1995), archaeological finds (Gulisano, 1995) and a Roman trade route completion (Via Decia) through Sonthofen $(20 \mathrm{~km} \mathrm{~N})$ around $250 \mathrm{CE}$ (Heuberger, 1955). We therefore suggest that people may have used the valley's slopes, which led to the observed MAR rise in HFL and LAD around the 3rd century cal CE. We also observe an elevated $\mathrm{Pb} \mathrm{EF}$ around $100 \mathrm{cal} \mathrm{CE}$, but in contrast to Mackensen (1995), we cannot firmly connect that to local Roman mining around Sonthofen. As strong $\mathrm{Pb}$ emissions of Roman origin are recorded across Europe (e.g. De Vleeschouwer et al., 2010b), we tend to attribute the enrichment in HFL to diffuse distal sources.

After $400 \mathrm{cal} \mathrm{CE}$, increased Abies alba pollen indicate forest expansion in cool and humid conditions. The absence of herbs (e.g. Plantago) and Corylus suggests a low human influence in the Kleinwalser Valley. In parallel to the forest expansion and decreased anthropogenic pollen indicators, the MAR dropped significantly in the first half of the 6th century calCE. Similar patterns were observed in the Kleinwalser Valley (Grosse-Brauckmann, 2002) as well as north of it (Rösch, 1992; Stojakowits, 2014). A wetter climate around 400 cal CE was directly followed by colder summer temperatures from 536 to 660 cal CE (Büntgen et al., 2011, 2016), called the Late Antique Little Ice Age (LALIA). Around this period, Holzhauser et al. (2005) observed glacier advances in the Swiss Alps. The comparison of our data with these palaeoclimate records suggests that due to a climatic deterioration between 500 and $600 \mathrm{cal} \mathrm{CE}$, human activities in the Kleinwalser Valley and its surroundings declined significantly. Moreover, erosion decreased as a combined result of forest expansion and soil stabilisation.

\subsection{0 cal CE to 2016 CE: from early Middle Ages to modern times}

This period saw the expansion of the Frankish empire to higher elevations, but little is known about it in this part of the northern central Alps, as neither Roman nor Middle Age historical sources exist (Babucke, 1995). We nevertheless observe a growing human impact in HFL, reflected in increasing cultural pollen proportions (Juglans, Cerealia, Plantago), which fits to deforestation and settlement expansion in the Alpine foreland suggested by Friedmann and Stojakowits (2017). The MAR in HFL also increased sharply after the LALIA to peak around $700 \mathrm{calCE}$, which is in accordance with observations in the Alps of Tinner et al. (2003). However, a sharp drop at $770 \mathrm{cal} C \mathrm{CE}$ was then followed by a decreasing trend along with the Medieval climatic optimum (900 to 1300 CE) (Mann, 2002) until the onset of the Little Ice Age glacier progressions (1300 to $1850 \mathrm{CE}$ ) (Matthews and Briffa, 2005). The MAR decrease indicates a landscape stabilisation. Historical sources indeed suggested that the Kleinwalser Valley has been managed for cattle herding and hunting since at least the 11th century CE (Amann, 2013a). The Walser arrived in the early 14th century CE and should have been responsible for most of the changes since then (Wagner, 1950). The presence of macro-charcoal $(>1 \mathrm{~mm})$ in HFL after $1350 \mathrm{cal} C \mathrm{CE}$ is in line with the onset of Walser settlements and indicates intense use of fire across the valley. The uppermost pollen sample in HFL shows the highest proportion of cultural and open landscape indicators (Fig. 3). However, our palynological resolution is coarse and our age-depth model is limited for that period, placing this uppermost sample in the early period of industrialisation (ca $1880 \mathrm{cal}$ CE). We can therefore assume that the Walser intensified deforestation until the mid-19th century, as shown on a land cover map from $1857 \mathrm{CE}$ (State of Vorarlberg, 2018). The MAR progressively increased from the 13th century cal CE towards the industrial period, reflecting a growing population, increasing forestry and agro-pastoral activities (dairy and meat production). However, this accelerating trend to landscape opening may have been buffered by early land (forest) management regulations (Amann, 2014; Fink and von Klenze, 1891), mitigating further destabilisation of land cover.

In contrast to HFL, the MAR in LAD seems to have taken another development between the Middle Ages and industrialisation. Even if the accumulation rates in this part need to be considered with caution, the MAR rose quite strongly after around $1400 \mathrm{calCE}$. Particularly this western side of the valley started to be used for cattle grazing after $1450 \mathrm{CE}$ (Amann, 2013b). Consequently, the vulnerable slopes suffered from erosion, induced by timber cutting and cattle trampling.

$\mathrm{Pb}$ EF has also increased since around $1400 \mathrm{cal}$ CE. Part of this increase may be attributed to the Sonthofen mining district, where exploitation was first documented for $1471 \mathrm{calCE}$ (Merbeler, 1995). However, the emergence of widespread European mining activities in the Middle Ages (e.g. Forel et al., 2010; Le Roux et al., 2005) could have contributed to the signal in HFL. The interpretation of the late Middle Ages in the LAD record is however limited by the age constraint. A more detailed discussion would therefore be speculative. We can however observe that the trends described above for $\mathrm{Pb} \mathrm{EF}$, the MAR, and pollen in HFL continued towards the 19th century. We can moreover suggest several interpretations from our geochemical data for the late 19th and 20th centuries. As a result of heavy industry and the introduction of leaded gasoline in Europe, the $\mathrm{Pb} \mathrm{EF}$ in HFL strongly increased continuously from $1850 \mathrm{cal} C E$ to a maximum of 250 in the 1980s and a sharp decline thereafter, perfectly fitting to the maximum use of leaded fuel and its subsequent ban (Pacyna and Pacyna, 2001). The chronology of the last centuries is however not well constrained. This could have been caused partly by drainage of Hoefle Mire, which temporarily reduced peat accumulation and enhanced 
decomposition at intermediate depth. However, our $\mathrm{Pb} \mathrm{EF}$ profile is strikingly similar to the well-dated $\mathrm{Pb}$ EF profile of several Swiss mires (Shotyk et al., 1998; Weiss et al., 1999) and, hence, provides another chronological reference point for the topmost part of the Hoefle core. We can therefore say that, during the first half of the 20th century, the MAR remained low in both mires. The tourism intensification in the valley (Fritz, 1981) and the construction of related infrastructure increased the MAR in both mires again after 1950 cal CE.

\section{Conclusions}

We present two peat records of the central Alps covering the last 6200 years. By combining geochemical, palynological and chronological tools, we are able to understand the occupation and high human impact on the landscape in a valley of the northern central Alps and beyond. Calibrating a portable geochemical tool with ICP-MS also allows us to quantify geochemical elements in peat at a resolution that is rarely obtained and demonstrates its potential in (palaeo)environmental studies.

A cooler and wetter climate around 6200 cal BP promoted mire formation in the Kleinwalser Valley. Pollen spectra and erosion suggest human presence in the valley as early as around $5700 \mathrm{cal} \mathrm{BP}$, lasting over several centuries, which is in line with studies on regional occupation. Increased $\mathrm{Pb} \mathrm{EF}$ values around the same time suggest metallurgical activities in the area, which predates regional archaeological evidence by almost 2000 years. Large-scale deforestation and land use (agro-pastoralism) took place between 3500 and 2800 cal BP causing a drastic landscape opening and high initial erosion rates at both low and high elevations. At the end of this period, a prominent $\mathrm{Pb} \mathrm{EF}$ points to metallurgical activities. However, landscape stabilised and forests recovered thereafter until well into the Roman period. A second period of increased erosion and land use started after $230 \mathrm{calCE}$ to a climax at around $700 \mathrm{calCE}$. This increased land use period was interrupted by climatic deteriorations around 500 to 600 cal CE. Pb EF increased during the Roman period. It is however challenging to identify an origin as Roman $\mathrm{Pb}$ pollution was widespread. The Middle Ages saw progressive land management and the arrival of the Walser people. While historical sources point to a strong Walser influence on the area, our data only allow us to suggest that deforestation, agriculture and pastoralism continued during that period. The extent of those activities remains unclear however. The Pb EF increased during Late Middle Ages. It then rose faster during the industrial revolution and peaked before leaded gasoline was banned, allowing us to use it as a chronological marker to constrain the last century, which saw increasing tourism and its consequences taking place in the Kleinwalser Valley.

Although several archaeological findings and sites gave evidence for three prehistoric hotspots of human activity be- fore, our pollen and geochemical data allow us to detail the evolution of the local and regional landscape and its use in the northern central Alps. The combination of historical sources with erosion indicators and pollen points to local land use and human presence in the valley thousands of years before the Walser arrival. Because the landscape had already undergone strong anthropogenic changes before, the recorded impact of the Walser was ultimately less prominent than could be expected.

Data availability. The geochemical data underlying this study are given either in the tables of the article or in the Supplement published with this article. The pollen data can be requested by contacting the first author.

Supplement. The supplement related to this article is available online at: https://doi.org/10.5194/egqsj-68-13-2019-supplement.

Author contributions. As corresponding author, CvS was responsible for planning and carrying out field work, geochemical analyses, data processing, and designing and writing of the paper. The pollen analyses were conducted by AL, whereas FDV contributed to sample preparation, geochemical analyses and designing of the paper. Both IU and JS helped in planning and conducting field sampling and contributed to the interpretation process.

Competing interests. The authors declare that they have no conflict of interest.

Special issue statement. This article is part of the special issue "Connecting disciplines - Quaternary archives and geomorphological processes in a changing environment". It is a result of the First Central European Conference on Geomorphology and Quaternary Sciences, Gießen, Germany, 23-27 September 2018.

Acknowledgements. We would like to thank Karl Keßler (landscape conservation Kleinwalser Valley), Alexander Suhm (Kiel University), Chuxian Li, Marie-Jo Tavella and Gaël Le Roux (all EcoLab) for their help and advice during field and laboratory phases. Clemens von Scheffer benefited from several travel grants from PPP (no. 57316724)/PHC-PROCOPE, no. 37646SG from DAAD/Campus-France (funded by the BMBF - German Federal Ministry of Education and Research), "Soutien à la Mobilité Internationale 2017" from the Institut National Polytechnique de Toulouse and a co-tutelle grant from the Deutsch-Französische Hochschule/Université franco-allemande (DFH/UFA). The project was co-funded through the graduate school "Human development in landscapes” (DFG-Excellence Initiative, GSC-208). 
Amann, A.: Alpleben im Walsertal - ein kulturhistorischer Abriss, in: Das Buoch soll Kraft und Macht haben, Alpbücher im Kleinwalsertal, 1541-1914, edited by: Amann, A. and Willand, D., 11-80, Brüüge, Riezlern/Kleinwalsertal, 2013a.

Amann, A.: Kaleidoskop der Alpbücher, in: Das Buoch soll Kraft und Macht haben, Alpbücher im Kleinwalsertal 1541-1914, edited by: Willand, D. and Amann, A., 103-164, Brüüge, Riezlern/Kleinwalsertal, 2013b.

Amann, A.: Alpgenossenschaften im Kleinwalsertal - Eine Vignette aus früherer Zeit "Berichte aus Alpbüchern des Alters 1592 AD”, in: Genossenschaftswissenschaft zwischen Theorie und Geschichte: Festschrift für Prof. Dr. Johann Brazda zum 60. Geburtstag, edited by: Laurinkari, J., Schediwy, R., and Todev, T., 49-63, BoD - Books on Demand, 2014.

Armit, I., Swindles, G. T., Becker, K., Plunkett, G., and Blaauw, M.: Rapid climate change did not cause population collapse at the end of the European Bronze Age, P. Natl. Acad. Sci. USA, 111, 17045-17049, 2014.

Artioli, G., Angelini, I., Kaufmann, G., Canovaro, C., Dal Sasso, G., and Villa, I. M.: Long-distance connections in the Copper Age: New evidence from the Alpine Iceman's copper axe, edited by: Hart, J. P., PLoS One, 12, e0179263, https://doi.org/10.1371/journal.pone.0179263, 2017.

Babucke, V.: Das frühe Mittelalter, in Kempten und das Allgäu, Führer zu archäologischen Denkmälern in Deutschland 30, edited by: Czysz, W., Dietrich, H., and Weber, G., 70-78, Theiss, Stuttgart, 1995.

Bachnetzer, T.: Prähistorischer Feuersteinbergbau im Kleinwalsertal, Vorarlberg, Silex- und Bergkristallabbaustellen in Österreich, Praearchos, 5, 2017.

Bächtiger, K.: Die Erzvorkommen und Lagerstätten Graubündens und der ehemalige Bergbau, Mitteilungen, Verein der Freunde des Bergbaues Graubünden, 21, 2-12, 1982.

Baron, S., Lavoie, M., Ploquin, A., Carignan, J., Pulido, M., and De Beaulieu, J. L.: Record of metal workshops in peat deposits: History and environmental impact on the Mont Lozère Massif, France, Environ. Sci. Technol., 39, 5131-5140, https://doi.org/10.1021/es0481651, 2005.

Barry, R. G.: Changes in mountain environments: a review, in Mountain Environments in Changing Climates, edited by: Beniston, M., 496, Taylor \& Francis, 2002.

Bartelheim, M., Eckstein, K., Huijsmans, M., Krauß, R., and Pernicka, E.: Kupferzeitliche Metallgewinnung in Brixlegg, Österreich, in: Die Anfänge der Metallurgie in der Alten Welt, edited by: Bartelheim,M., Pernicka, E., and Krause, R., 33-82, Rahden, Westfalia: Verlag Marie Leidorf, Rahden, 2002.

Bätzing, W.: Die Alpen: Geschichte und Zukunft einer europäischen Kulturlandschaft, 4th ed., C.H. Beck, Munich, 2015.

Blaauw, M.: Methods and code for "classical" age-modelling of radiocarbon sequences, Quat. Geochronol., 5, 512-518, 2010.

Blaauw, M. and Christen, J. A.: Flexible paleoclimate age-depth models using an autoregressive gamma process, Bayesian Anal., 6, 457-474, https://doi.org/10.1214/11-BA618, 2011.

Breitenlechner, E., Goldenberg, G., Lutz, J., and Oeggl, K.: The impact of prehistoric mining activities on the environment: A multidisciplinary study at the fen Schwarzenbergmoos (Brix- legg, Tyrol, Austria), Veg. Hist. Archaeobot., 22, 351-366, https://doi.org/10.1007/s00334-012-0379-6, 2013.

Büntgen, U., Tegel, W., Nicolussi, K., McCormick, M., Frank, D., Trouet, V., Kaplan, J. O., Herzig, F., Heussner, K. U., Wanner, H., Luterbacher, J., and Esper, J.: 2500 years of European climate variability and human susceptibility, Science, 80, 331, 578-582, https://doi.org/10.1126/science.1197175, 2011.

Büntgen, U., Myglan, V. S., Ljungqvist, F. C., McCormick, M., Di Cosmo, N., Sigl, M., Jungclaus, J., Wagner, S., Krusic, P. J., Esper, J., Kaplan, J. O., De Vaan, M. A. C., Luterbacher, J., Wacker, L., Tegel, W., and Kirdyanov, A. V.: Cooling and societal change during the Late Antique Little Ice Age from 536 to around 660 AD, Nat. Geosci., 9, 231-236, https://doi.org/10.1038/ngeo2652, 2016.

Carcaillet, C.: A spatially precise study of Holocene fire history, climate and human impact within the Maurienne valley, North French Alps, J. Ecol., 86, 384-396, https://doi.org/10.1046/j.1365-2745.1998.00267.x, 1998.

Clark, A. J. S., Merkt, J., and Muller, H.: Post-Glacial Fire, Vegetation, and Human History on the Northern Alpine Forelands, South-Western Germany, J. Ecol., 77, 897-925, 1989.

Clegg, E. J., Harrison, G. A. and Baker, P. T.: The impact of high altitudes on human populations, Hum. Biol., 42, 486-518, 1970.

Cornelissen, M. and Reitmaier, T.: Filling the gap: Recent Mesolithic discoveries in the central and south-eastern Swiss Alps, Quatern. Int., 423, 9-22, https://doi.org/10.1016/j.quaint.2015.10.121, 2016.

de Graaff, L. W. S., de Jong, M. G. G., Busnach, T., and Seijmonsbergen, A. C.: Geomorphologische Studie hinterer Bregenzerwald, Bericht an das Amt der Vorarlberger Landesregierung, Abt. Raumplanung und Baurecht Landhaus Bregenz, Amsterdam, 2003.

Della Casa, P.: Switzerland and the Central Alps, in The Oxford Handbook of the European Bronze Age, edited by: Harding, A. and Fokkens, H., 706-722, OUP Oxford, 2013.

Dertsch, R.: Ortsnamensbuch des Landkreises Sonthofen, Historisches Ortsnamenbuch von Bayern, Schwaben, Bd. 7, Kommission für Bayerische Landesgeschichte, München, 1974.

De Vleeschouwer, F., Chambers, F. M., and Swindles, G. T.: Coring and sub-sampling of peatlands for palaeoenvironmental research, Mires Peat, 7, 1-10, https://doi.org/10.1016/j.ssi.2010.01.014, 2010a.

De Vleeschouwer, F., Le Roux, G., and Shotyk, W.: Peat as an archive of atmospheric pollution and environmental change: A case study of lead in Europe, PAGES Mag., 18, 20-22, https://doi.org/10.22498/pages.18.1.20, 2010b.

Dieffenbach-Fries, H.: Zur spät- und postglazialen Vegetationsentwicklung bei Oberstdorf (Oberallgäu) und im kleinen Walsertal (Vorarlberg), Technische Hochschule Darmstadt, 1981.

Dietre, B., Walser, C., Kofler, W., Kothieringer, K., Hajdas, I., Lambers, K., Reitmaier, T., and Haas, J. N.: Neolithic to Bronze Age (4850-3450 cal. BP) fire management of the Alpine Lower Engadine landscape (Switzerland) to establish pastures and cereal fields, Holocene, 27, 181-196, https://doi.org/10.1177/0959683616658523, 2017.

El Balti, N., Christ, L., Kempke, M., Martens, T., Bork, H., and Schrautzer, J.: Die Moore im Kleinwalsertal - Aktueller Zustand und Entwicklungsmöglichkeiten, Ina. - Forsch. online, 40.1, 2017. 
Festi, D., Putzer, A., and Oeggl, K.: Mid and late holocene land-use changes in the Ötztal alps, territory of the neolithic iceman "Ötzi”, Quatern. Int., 353, 17-33, https://doi.org/10.1016/j.quaint.2013.07.052, 2014.

Fink, J. and von Klenze, H.: Der Mittelberg. Geschichte, Landesund Volkskunde des ehemaligen gleichnamigen Gerichtes (Reprint), Kösel, Kempten, 1891.

Forel, B., Monna, F., Petit, C., Bruguier, O., Losno, R., Fluck, P., Begeot, C., Richard, H., Bichet, V., and Chateau, C.: Historical mining and smelting in the Vosges Mountains (France) recorded in two ombrotrophic peat bogs, J. Geochem. Explor., 107, 9-20, https://doi.org/10.1016/j.gexplo.2010.05.004, 2010.

Frank, C. and Pernicka, E.: Copper artefacts of the Mondsee group and their possible sources, in: Lake Dwellings after Robert Munro, Proceedings from the Munro International Seminar: The Lake Dwellings of Europe. 22nd 23rd October 2010, University of Edinburgh, edited by: Midgley, M. S. and Sanders, J., 113138, Sidestone press, Leiden, 2012.

Friedmann, A. and Stojakowits, P.: Zur spät- und postglazialen Vegetationsgeschichte des Allgäu mit Alpenanteil, Kontrakpunkte: Festschrift für Manfred Rösch, edited by: Lechterbeck, J. and Fischer, E., Verlag Dr. Rudolf Habelt GmbH, Bonn, 2017.

Fritz, W.: Kleinwalsertal einst und jetzt: heimatkundliche Betrachtungen, Verlag Walserdruck, Erich Stöckeler, Riezlern/Kleinwalsertal, 1981.

Givelet, N., Le Roux, G., Cheburkin, A., Chen, B., Frank, J., Goodsite, M. E., Kempter, H., Krachler, M., Noernberg, T., Rausch, N., Rheinberger, S., Roos-Barraclough, F., Sapkota, A., Scholz, C., and Shotyk, W.: Suggested protocol for collecting, handling and preparing peat cores and peat samples for physical, chemical, mineralogical and isotopic analyses, J. Environ., 6, 481-492, https://doi.org/10.1039/B401601G, 2004.

Goldscheider, N.: Hydrogeologische Untersuchungen im alpinen Karstgebiet Gottesacker und Schwarzwassertal (Allgäu/Vorarlberg), Vor. Naturschau, 4, 247-294, available at: http://www.biologiezentrum.at (last access: 17 September 2018), 1998.

Grimm, E. C.: Tilia software v. 2.0.60, Illinois State Museum, Springf., 2018.

Grosse-Brauckmann, G.: Paläobotanische Befunde von zwei Mooren im Gebiet des Hohen Ifen, Vorarlberg (Österreich), Telma, 32, 17-36, 2002.

Gulisano, G.: Neue mittelsteinzeitliche Fundplätze im oberen Illertal und im Kleinwalsertal, Archäologische Informationen, 17, 79-84, https://doi.org/10.11588/ai.1994.1.35418, 1994.

Gulisano, G.: Die Besiedlung des Kleinwalsertales und seiner angrenzenden Gebiete in Bayern und Vorarlberg von der Steinzeit bis zur Einwanderung der Walser, Archäologische Informationen, 18, 53-65, https://doi.org/10.11588/ai.1995.1.35421, 1995.

Haas, J. N., Richoz, I., Tinner, W., and Wick, L.: Synchronous holocene climatic oscillations recorded on the Swiss plateau and at timberline in the alps, Holocene, 8, 301-309, https://doi.org/10.1191/095968398675491173, 1998.

HDÖ: Die Niederschläge, Schneeverhältnisse und Lufttemperaturen in Österreich im Zeitraum 1981-1991, Beiträge zur Hydrographie Österreichs, Vienna, 1994.

Heuberger, R.: Der Bodenseeraum im Altertum, in Aus Verfassungs- und Landesgeschichte, Festschrift für Theodor Mayer zum 70. Geb. Band 2. Geschichtliche Landesforschung,
Wirtschaftsgeschichte u. Hilfswissenschaften, edited by: Büttner, H., Feger, O., and Meyer, B., 7-21, Lindau/Konstanz, 1955.

Hölzer, A. and Hölzer, A.: Silicon and titanium in peat profiles as indicators of human impact, Holocene, 8, 685-696, https://doi.org/10.1191/095968398670694506, 1998.

Holzhauser, H., Magny, M., and Zumbühl, H. J.: Glacier and lake-level variations in west-central Europe over the last 3500 years, Holocene, 15, 789-801, https://doi.org/10.1191/0959683605hl853ra, 2005.

Höppner, B., Bartelheim, M., Huijsman, M., Krauss, R., Martinek, K.-P., Pernicka, E., and Schwab, R.: Prehistoric copper production in the Inn Valley (Austria), and the earliest copper in Cental Europe, Archaeometry, 47, 293-315, https://doi.org/10.1111/j.1475-4754.2005.00203.x, 2005.

Hormes, A., Müller, B. U., and Schlüchter, C.: The Alps with little ice: Evidence for eight holocene phases of reduced glacier extent in the Central Swiss Alps, Holocene, 11, 255-265, https://doi.org/10.1191/095968301675275728, 2001.

Ivy-Ochs, S., Kerschner, H., Maisch, M., Christl, M., Kubik, P. W., and Schlüchter, C.: Latest Pleistocene and Holocene glacier variations in the European Alps, Quaternary Sci. Rev., 28, $2137-$ 2149, https://doi.org/10.1016/j.quascirev.2009.03.009, 2009.

Jacomet, S.: Plant economy and village life in Neolithic lake dwellings at the time of the Alpine Iceman, Veg. Hist. Archaeobot., 18, 47-59, https://doi.org/10.1007/s00334-007-01382, 2009.

Kalnicky, D. J. and Singhvi, R.: Field portable XRF analysis of environmental samples, J. Hazard. Mater., 83, 93-122, https://doi.org/10.1016/S0304-3894(00)00330-7, 2001.

Le Roux, G., Aubert, D., Stille, P., Krachler, M., Kober, B., Cheburkin, A., Bonani, G., and Shotyk, W.: Recent atmospheric $\mathrm{Pb}$ deposition at a rural site in southern Germany assessed using a peat core and snowpack, and comparison with other archives, Atmos. Environ., 39, 6790-6801, https://doi.org/10.1016/j.atmosenv.2005.07.026, 2005.

Leitner, W.: Der Felsüberhang auf der Schneiderkürenalpe - Ein Jäger- und Hirtenlager der Vorzeit, Bergschau, 1, 1-32, 2003.

Löwemark, L., Chen, H. F., Yang, T. N., Kylander, M., Yu, E. F., Hsu, Y. W., Lee, T. Q., Song, S. R., and Jarvis, S.: Normalizing XRF-scanner data: A cautionary note on the interpretation of high-resolution records from organic-rich lakes, J. Asian Earth Sci., 40, 1250-1256, https://doi.org/10.1016/j.jseaes.2010.06.002, 2011.

Lutz, J. and Pernicka, E.: Prehistoric copper from the Eastern Alps, Open J. Archaeom., 1, 122-127, https://doi.org/10.4081/arc.2013.e25, 2013.

Mackensen, M.: Die spätrömische Grenze im Gebiet von Cambidano-Kempten, in: Kempten und das Allgäu, Führer zu archäologischen Denkmälern in Deutschland 30, edited by: Czysz, W., Dietrich, H., and Weber, G., 61-69, Theiss, Stuttgart, 1995.

Magny, M., Galop, D., Bellintani, P., Desmet, M., Didier, J., Haas, J. N., Martinelli, N., Pedrotti, A., Scandolari, R., Stock, A., and Vannière, B.: Late-Holocene climatic variability south of the Alps as recorded by lake-level fluctuations at Lake Ledro, Trentino, Italy, Holocene, 19, 575-589, https://doi.org/10.1177/0959683609104032, 2009. 
Mann, M. E.: Medieval Climatic Optimum, Encycl. Glob. Environ. Chang., 1, 514-516, 2002.

Mansel, K.: Ein latènezeitlicher Schlüssel mit Stierplastik aus Sonthofen im Allgäu, Germania, 67, 572-587, 1989.

Matthews, J. A. and Briffa, K. R.: The "Little Ice Age": Reevaluation of an evolving concept, Geogr. Ann. Ser. A, 87, 1736, https://doi.org/10.1111/j.0435-3676.2005.00242.x, 2005.

McLennan, S. M.: Relationships between the trace element composition of sedimentary rocks and upper continental crust, Geochem. Geophy. Geosy., 2, 2000GC000109, https://doi.org/10.1029/2000GC000109, 2001.

Mejía-Piña, K. G., Huerta-Diaz, M. A., and González-Yajimovich, O.: Calibration of handheld X-ray fluorescence (XRF) equipment for optimum determination of elemental concentrations in sediment samples, Talanta, 161, 359-367, https://doi.org/10.1016/j.talanta.2016.08.066, 2016.

Merbeler, J.: Erzbergbau und Verhüttung im Starzlachtal, in: Kempten und das Allgäu, Führer zu archäologischen Denkmälern in Deutschland 30, edited by: Czysz, W., Dietrich, H., and Weber, G., 149-152, Theiss, Stuttgart, 1995.

Moore, P., Webb, J., and Collinson, M.: Pollen Analysis, Blackwell Scientific Publications Ltd, Oxford, 1991.

Nesbitt, H. W. and Markovics, G.: Weathering of granodioritic crust, long-term storage of elements in weathering profiles, and petrogenesis of siliciclastic sediments, Geochim. Cosmochim. Ac., 61, 1653-1670, https://doi.org/10.1016/S00167037(97)00031-8, 1997.

Oblinger, H.: Blei- und Zinkerz am Roßkopf (Ostrachtal/Allgäuer Alpen), Berichte des Naturwissenschaftlichen Vereins für Schwaben e.V., 100, 85-90, 1996.

O'Brien, W.: Prehistoric Copper Mining in Europe: 5500-500 BC, Oxford University Press, 2015.

Oeggl, K. and Nicolussi, K.: Prähistorische Besiedlung von zentralen Alpentälern in Bezug zur Klimaentwicklung, in: Klimawandel in Österreich: die letzten 20.000 Jahre und ein Blick voraus, edited by: Schmidt, R., Psenner, R., and Matulla, C., 7786, Innsbruck university press, 2009.

Pacyna, J. M. and Pacyna, E. G.: An assessment of global and regional emissions of trace metals to the atmosphere from anthropogenic sources worldwide, Environ. Rev., 9, 269-298, https://doi.org/10.1139/er-9-4-269, 2001.

R Core Team: R: A Language and Environment for Statistical Computing, available at: https://www.r-project.org/ (last access: 14 April 2019), 2017.

Reimer, P. J., Bard, E., Bayliss, A., Beck, J. W., Blackwell, P. G., Ramsey, C. B., Buck, C. E., Cheng, H., Edwards, R. L., Friedrich, M., Grootes, P. M., Guilderson, T. P., Haflidason, H., Hajdas, I., Hatté, C., Heaton, T. J., Hoffmann, D. L., Hogg, A. G., Hughen, K. A., Kaiser, K. F., Kromer, B., Manning, S. W., Niu, M., Reimer, R. W., Richards, D. A., Scott, E. M., Southon, J. R., Staff, R. A., Turney, C. S. M., and van der Plicht, J.: IntCal13 and Marine13 Radiocarbon Age Calibration Curves 0-50 000 Years cal BP, Radiocarbon, 55, 1869-1887, https://doi.org/10.2458/azu_js_rc.55.16947, 2013.

Reitmaier, T., Doppler, T., Pike, A. W. G., Deschler-Erb, S., Hajdas, I., Walser, C., and Gerling, C.: Alpine cattle management during the Bronze Age at Ramosch-Mottata, Switzerland, Quatern. Int., 484, 19-31, https://doi.org/10.1016/j.quaint.2017.02.007, 2018.
Roepke, A. and Krause, R.: High montane-subalpine soils in the Montafon Valley (Austria, northern Alps) and their link to landuse, fire and settlement history, Quatern. Int., 308-309, 178-189, https://doi.org/10.1016/j.quaint.2013.01.022, 2013.

Roepke, A., Stobbe, A., Oeggl, K., Kalis, A. J., and Tinner, W.: Late-Holocene land-use history and environmental changes at the high altitudes of St Antönien (Switzerland, Northern Alps): Combined evidence from pollen, soil and tree-ring analyses, Holocene, 21, 485-498, https://doi.org/10.1177/0959683610385727, 2011.

Rösch, M.: Human impact as registered in the pollen record: some results from the western Lake Constance region, Southern Germany, Veg. Hist. Archaeobot., 1, 101-109, https://doi.org/10.1007/BF00206090, 1992.

Schmidl, A. and Oeggl, K.: Land Use in the Eastern Alps During the Bronze Age - an Archaeobotanical Case Study of a Hilltop Settlement in the Montafon (Western Austria), Archaeometry, 47, 455-470, https://doi.org/10.1111/j.1475-4754.2005.00213.x, 2005.

Schmidt-Thomé, P.: Zur Geologie und Morphologie des Ifengebirgsstockes (Allgäu): Erläuterungen zur topographischmorphologischen Kartenprobe VI 3: Alpiner Karst und Bergsturz (On the Geology and Morphology of the Hohe Ifen), Erdkunde, 14, 181-195, 1960.

Schrautzer, J., Bork, H.-R., Christ, L., El-Balti, N., Martens, T., Kempke, M., von Scheffer, C., and Unkel, I.: Classification, ecological characterization and development of montane mires, Phytocoenologia - J. Veg. Ecol., in press, 2019.

Shand, C. A. and Wendler, R.: Portable X-ray fluorescence analysis of mineral and organic soils and the influence of organic matter, J. Geochem. Explor., 143, 31-42, https://doi.org/10.1016/j.gexplo.2014.03.005, 2014.

Shotyk, W., Weiss, D., Appleby, P. G., Cheburkin, A. K., Frei, R., Gloor, M., Kramers, J. D., Reese, S., and Van der Knaap, W. O.: History of atmospheric lead depostion since $12,370^{14} \mathrm{C}$ yr BP from a Peat bog, Jura Mountains, Switzerland, Science, 281, 1635-1640, https://doi.org/10.1126/science.281.5383.1635, 1998.

Shotyk, W., Weiss, D., Kramers, J. D., Frei, R., Cheburkin, A. K., Gloor, M., and Reese, S.: Geochemistry of the peat bog at Etang de la Gruère, Jura Mountains, Switzerland, and its record of atmospheric $\mathrm{pb}$ and lithogenic trace metals ( $\mathrm{Sc}, \mathrm{Ti}, \mathrm{Y}, \mathrm{Zr}$, and REE) since $12,370{ }^{14} \mathrm{C}$ yr bp, Geochim. Cosmochim. Ac., 65, 23372360, https://doi.org/10.1016/S0016-7037(01)00586-5, 2001.

Shuttleworth, E. L., Evans, M. G., Hutchinson, S. M., and Rothwell, J. J.: Assessment of lead contamination in peatlands using field portable XRF, Water Air. Soil Pollut., 225, https://doi.org/10.1007/s11270-013-1844-2, 2014.

State of Vorarlberg: VoGIS, Vorarlberg Atlas, Urmappe 1857, available at: http://vogis.cnv.at/, last access: 17 August 2018.

Stojakowits, P.: Pollenanalytische Untersuchungen zur Rekonstruktion der Vegetationsgeschichte im südlichen Iller-WertachJungmoränengebiet seit dem Spätglazial (PhD-Thesis), Universität Augsburg, 2014.

Tinner, W., Lotter, A. F., Ammann, B., Conedera, M., Hubschmid, P., Van Leeuwen, J. F. N., and Wehrli, M.: Climatic change and contemporaneous land-use phases north and south of the Alps 2300 BC to 800 AD, Quaternary Sci. Rev., 22, 1447-1460, https://doi.org/10.1016/S0277-3791(03)00083-0, 2003. 
Tomedi, G., Staudt, M., and Töchterle, U.: Zur Bedeutung des prähistorischen Bergbaus auf Kupfererze im Raum SchwazBrixlegg, in: Cuprum Tyrolense - 5550 Jahre Bergbau und Kupferverhüttung in Tirol, edited by: Oeggl, K. and Schaffer, V., 55-70, Edition Tirol, 2013.

Valese, E., Conedera, M., Held, A. C. C., and Ascoli, D.: Fire, humans and landscape in the European Alpine region during the Holocene, Anthropocene, 6, 63-74, https://doi.org/10.1016/j.ancene.2014.06.006, 2014.

Van der Knaap, W. O., van Leeuwen, J. F. N., and Ammann, B.: The first rise and fall of Fagus sylvatica and interactions with Abies alba at Faulenseemoos (Weiss Plateau) 6900-6000 cal yr BP, Acta Palaeobot., 44, 249-266, 2004.

Vanneste, H., De Vleeschouwer, F., Martínez-Cortizas, A., von Scheffer, C., Piotrowska, N., Coronato, A., and Le Roux, G.: Late-glacial elevated dust deposition linked to westerly wind shifts in southern South America, Sci. Rep., 5, 11670, https://doi.org/10.1038/srep11670, 2015.

Völk, H. R.: Geomorphologie des Kleinwalsertales und seiner Gebirgsumrahmung, Landschaftsformen zur Eiszeit und Nacheiszeit unter Einbeziehung der geologischen Verhältnisse, Vor. Naturschau, 10, 7-95, 2001.

von Gümbel, C. W.: Geognostische Beschreibung des Königreichs Bayern: Geognostische Beschreibung des bayerischen Alpengebirges und seines Vorlandes, bayer. Staatsministerium der Finanzen, Gotha, 1861.

von Raiser, J. N.: Der Ober-Donau-Kreis des Königreichs Bayern unter den Römern, Die Römer-Male von Augusta rauracum bis Augusta Vindelicorum: 1, Kranzfelder, Augsburg, 1830.

Vorren, K.-D., Mørkved, B,. and Bortenschlager, S.: Human impact on the Holocene forest line in the Central Alps, Veg. Hist. Archaeobot., 2, 145-156, https://doi.org/10.1007/BF00198585, 1993.

Wagner, G.: Rund um Hochifen und Gottesackergebiet, Verlag der Hohenloheschen Buchhandlung Ferdinand Rau, Öhringen, 1950 .
Walde, C. and Oeggl, K.: Blütenstaub enthüllt 3000-jährige Siedlungsgeschichte im Tannberggebiet, Walserheimat Vor., Tirol und Liechtenstein, 73, 1-6, available at: https://www.vorarlbergerwalservereinigung.at/vwvwp/bluetenstaub (last access: 6 March 2019), 2003.

Walde, C. and Oeggl, K.: Neue Ergebnisse zur Siedlungsgeschichte am Tannberg. Die Pollenanalysen aus dem Körbersee, Walserheimat Vor., Tirol und Liechtenstein, 75, 4-7, available at: https://www.vorarlberger-walservereinigung.at/vwvwp/neueergebnisse (last access: 6 March 2019), 2004.

Weber, L.: Handbuch der Lagerstätten der Erze, Industrieminerale und Energierohstoffe Österreichs: Erläuterungen zur metallogenetischen Karte von Österreich 1:500 000 unter Einbeziehung der Industrieminerale und Energierohstoffe, Geologische Bundesanstalt, 1997.

Weber, M.: Die frühe und mittlere römische Kaiserzeit, in Kempten und das Allgäu, Führer zu archäologischen Denkmälern in Deutschland 30, edited by: Czysz, W., Dietrich, H., and Weber, G., 49-60, Theiss, Stuttgart, 1995.

Weiss, D., Shotyk, W., Appleby, P. G., Kramers, J. D., and Cheburkin, A. K.: Atmospheric $\mathrm{Pb}$ Deposition since the Industrial Revolution Recorded by Five Swiss Peat Profiles: Enrichment Factors, Fluxes, Isotopic Composition, and Sources, Environ. Sci. Technol., 33, 1340-1352, https://doi.org/10.1021/es980882q, 1999.

Wick, L. and Tinner, W.: Vegetation Changes and Umbertine Fluctuations in the Central Alps as Indicators of Holocene Climatic Oscillations, Arct. Alp. Res., 29, 445-458, https://doi.org/10.2307/1551992, 1997.

Wurth, G., Niggemann, S., Richter, D. K., and Mangini, A.: The Younger Dryas and Holocene climate record of a stalagmite from Hölloch Cave (Bavarian Alps, Germany), J. Quaternary Sci., 19, 291-298, https://doi.org/10.1002/jqs.837, 2004.

Zacher, W.: Geologische Karte von Österreich: Blatt 113 Mittelberg 1:50 000, Geologische Bundesanstalt, Wien, 1990. 